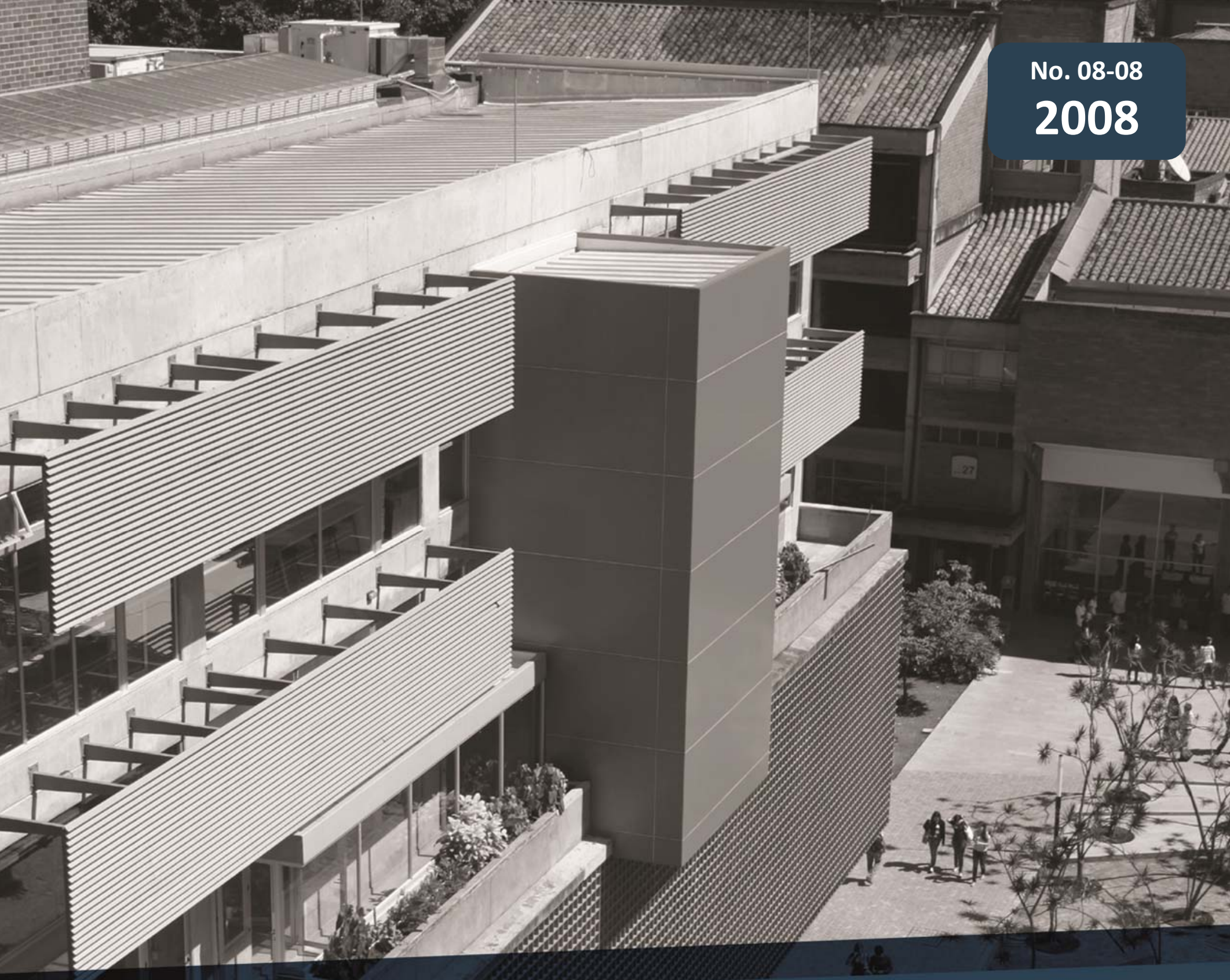

TOURISM AS A DRIVER OF ECONOMIC DEVELOPMENT:

THE COLOMBIAN EXPERIENCE.

Andreja Benković

Juan Felipe Mejía

Documentos de trabajo

Economía y Finanzas

Centro de Investigaciones Económicas y Financieras (CIEF)

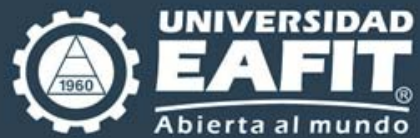




\title{
TOURISM AS A DRIVER OF ECONOMIC DEVELOPMENT: THE COLOMBIAN EXPERIENCE
}

\author{
Andreja BENKOVIĆ \\ University of Hohenheim \\ Department of Economic Theory (520H) \\ D - 70593 Stuttgart \\ E-mail address: benkovic@uni-hohenheim.de \\ Juan Felipe MEJÍA \\ University of Hohenheim \\ Department of Economic Theory (520H) \\ D - 70593 Stuttgart \\ E-mail address: jfmejia@uni-hohenheim.de
}

\begin{abstract}
:
The current paper analyzes the importance and potentials of the tourism sector for economic development. It is divided into four major parts. After a short introduction, section two presents some theoretical insights into the topic of economic development. Commenting on the most relevant components of the catching-up theory by Abramovitz (1986) and the structural change theory by Baumol (1967) and others, it could be realized that growth and the accompanying structural changes in the distribution of employment and GDP have their sources in the sector industry. But at the moment of incorporating the demand side explanation of structural change, the service sectors offer growth potentials as well. Furthermore, the basic characteristics and importance of the tourism sector for economic development and employment are emphasized, examining the so-called "social capabilities" and the innovation potential within the process of economic growth of any nation. A short survey of literature concerning the contribution of this sector to economic growth makes clear that tourism should be considered not just from the perspective of the benefits, but also from the costs associated with it.

Section three provides an analysis of the economic impact of tourism in a developing country, namely Colombia, based on time-series analysis and data gathered supported on the "Tourism Satellite Account" Methodology. Some relevant indicators produced by the World Economic Forum through its "Travel and Tourism Competitiveness Report", are also evaluated. Finally, some conclusions are drawn with respect to the potentialities, as well as the challenges identified for the Colombian case.
\end{abstract}

Keywords: structural change, service sectors, social capabilities, economic development, tourism, Colombia

JEL classification: L83, L86, L88, O1, O54, Q01, Q5 


\section{Introduction}

Colombia is defined by the World Bank as a middle income economy, taking into account its per capita GNI. According to the descriptive analysis of Abramovitz (1986) proposed by the so-called catching-up theory, this country could suit the definition of "followers". Along the vintage approach, this "lagging-behind" nation shows a potential for productivity and economic growth ("advantage of backwardness") through renewing its capital stock by adopting the "best-practice" technology being used by the "leaders" which incorporates new knowledge and techniques. Afterwards, these technologies support a learning process, and therefore promote the creation of its own innovations through R\&D efforts as well. But "the existence of a technology gap is a necessary but not sufficient condition for the process of technological catch-up. A country must also have sufficient 'absorptive capability' defined as the capability to access, learn and absorb relevant overseas technology" (Rogers, 2004, p. 578). This suggests that, in contrast to the neoclassical growth theory, which does not explain the reasons for technological change but a conditional convergence, Abramovitz (1986) provides an explanation of why some countries do or do not pass through a successful catching-up process. He identifies some specific characteristics which he aggregates under the definition of "social capabilities", as an important factor that strengthens economic growth and decides the convergence or divergence process of any nation. Although these "capabilities" are difficult to measure, these implications influence some reflections of the socalled "New" or "Endogenous" growth theory, as well as recent publications by Dyker and Radošević (2001). According to the main results of Temple and Johnson (1998) who used the so-called "Adelman-Morris Index", the striking finding is a "close relation between social development and per capita income" and that "countries with higher levels of socio-economic development invest more in physical capital and schooling" (Temple and Johnson, 1998, p. 974). At least, "conditions facilitating or hindering structural change in the composition of output, in the occupational and industrial distribution of the workforce, and in the geographical location of industry and population" (Abramovitz, 1986, p. 224) decide the pace of catching-up. This means that the willingness to break up current structures and replace them with new ones should be involved in the constantly changing "social capabilities". Thus, it is necessary to incorporate the sectoral composition of output and employment in the analysis, recognizing that each sector has a different catching-up potential depending inter alia on the role of human capital as well.

One intention of this paper is to attempt enlarging and investigating these inferences of the catching-up theory by complementing the analysis with some implications of the theory of structural change. The latter describes in general the transformation of the economic structure, as well as the composition of output and employment shares along the primary, secondary and, at least, tertiary sectors. One service sector of which science takes less notice is the tourism sector. Thus, it is surprising to see that the World Tourism Organization (UNWTO) states that the tourism sector has become "one of the largest and fastest growing economic sectors in the world", making reference to its contribution, especially for developing countries, in terms of employment generation, poverty alleviation and opportunities for development (UNWTO, 2008, p.1).

According to the same source, tourism has become one of the major international trade categories, and the export income generated by international tourism ranks fourth after fuels, chemicals and automotive products. One interesting trend identified is related to the appearance of new players: in 1950, the world's top 15 destinations absorbed $98 \%$ of all international tourist arrivals, in 1970 the proportion was 75\%, and this fell to 57\% in 2007. 
Many of these "newcomers" are, precisely, developing nations. When it comes to the world's top tourism destinations in terms of international tourism receipts, it is interesting to note how eight out of ten countries are developed nations (UNWTO, 2008, p.1). The fact that tourism is an important economic sector not just for developing, but for advanced nations as well, can not be ignored.

In the same line of argument, the World Economic Forum in its latest Travel and Tourism Competitiveness Report 2008 places special emphasis on the fact that the travel and tourism industry has become a key sector in the world economy, stressing its importance in terms of job creation and economic growth in many different countries of the world. Besides that, the World Travel and Tourism Council, resorting to the so-called Tourism Satellite Accounting Methodology (TSA), declares that the contribution of travel and tourism to the world's Gross Domestic Product (GDP) is expected to rise from $9.9 \%$ in 2008 to $10.5 \%$ by 2018 , and that the contribution of the travel and tourism economy to employment is expected to increase from $8.4 \%$ of total employment to $9.2 \%$ within the same period (http://www.wttc.org/eng/Tourism_Research/Tourism_Satellite_Accounting, 2007).

Thus, it is questionable how far the tourism sector is able to encourage sustained and stable economic growth. What are the main favourable opportunities and threats respectively for economic development through a specialisation in the tourism sector in general, whereby this sector itself is affected by structural changes in different ways? These have been questions frequently addressed by prominent economic studies and investigations. Whereas an important variety of research undertaken by some of the most reputed tourism international organizations both at the public and private level mostly emphasize the positive effects of this economic activity, an in-depth survey of the academic literature allows to encounter arguments discussing both the benefits and costs that tourism entails. First and foremost, it is pertinent to analyse and contrast both points of view. Furthermore, it is necessary to investigate the main characteristics of the service sectors and then, apply these findings to the tourism sector. All these findings are important for describing and estimating the potentialities of the tourism sector in Colombia and for the Colombian economy.

Section two of this paper offers some theoretical insights regarding economic development. Commenting on the most relevant components of the catching-up theory by Abramovitz (1986) and the structural change theory by Baumol (1967) and others, it could be realized that growth and the accompanying structural changes in the distribution of employment and GDP have their sources in the sector industry. But at the moment of incorporating the demand side explanation of structural change, the service sectors offer growth potentials as well. Furthermore, the basic characteristics and importance of the tourism sector for economic development and employment are emphasized, examining the so-called "social capabilities" and the innovation potential within the process of economic growth of any nation. A brief survey of literature concerning the contribution of this sector to economic growth makes clear that tourism should be considered both from the perspective of the benefits and costs that it implies.

Section three provides an analysis of the importance and dimension of the tourism sector within the Colombian economy, in terms of foreign currency generation, GDP, employment, FDI, and capital investments. Based on the World Travel and Tourism Council's Tourism Satellite Account methodology and its derived data, it is possible to estimate the full impact of tourism for the whole economy. Another very valuable input for the analysis is provided by 
the recently introduced World Economic Forum's Travel and Tourism Competitiveness Index, which allows appreciating the strengths and weaknesses of the Colombian tourism sector.

Section four provides some policy recommendations and conclusions, essentially proposing how the incorporation of ICTs and the enhancement of "social capabilities" in Colombia, especially in the field of education, are crucial elements to be considered for guaranteeing that tourism can play an effective role when supporting economic growth and alleviating poverty in the country.

\section{Some theoretical considerations regarding economic development and the tourism sector}

\subsection{Theoretical implications of the structural change theory}

One of the most well-known explanations of structural change of an economy is the threesector-hypothesis. Economists like Fisher (1935), Clark (1940), Fourastié (1949) and Wolfe (1955) investigate the interaction of several demand and supply side factors whereby the final stage and the so-called "Grand Espoir" of the twentieth century describe an economy mainly consisting of service sector activities.

Until the statement of Clark that half of the labour population of Britain and the USA worked at least in the tertiary sector, services were declared as a part of vertically integrated production activities in the two other sectors. Also Smith and Ricardo described services as a residual of goods production by affecting mainly the distribution and consumption of wealth. Services are being characterised as "intangible", thus, "invisible" and "non-tradable" acting mainly on domestic markets at local and regional levels. The production and consumption of services is carried out simultaneously, i.e. consumers and service providers interact intermediately (uno-actu-principle). Furthermore, the service sectors consist mainly of small firms which are not able to exploit economies of scale (EOS) and thus, have little potentiality to expand. Also the definition of the Gross National Product of the former Eastern European countries was borrowed from the Marxian division. On the one hand, services like education, health or services of the state are considered as un-productive due to the less intensive use of physical capital. On the other hand, business-related services (transport, trade), and returns from the tourism sector which are covered in the material product system are (more) productive because they contribute to production or distribution of goods.

The question of "un-productivity" of services is indeed the main contentious issue in theoretical approaches. In general, the main and exogenous determinant accelerating this development is the overall productivity growth which is caused by a different distribution of technological progress in the form of product or process innovations, with the result of different rates of sectoral TFP growth.

One of the most discussed approaches is the unbalanced-growth and two-sector-model of Baumol (1967). According to the empirical evidence of the 1960s and based on the typical neoclassical assumptions, he describes a "progressive" sector, i.e. manufacturing, where new technology is used with possibilities of capital accumulation and EOS by automation and mass production. The service sector, the so-called "stagnant" with low or zero technological progress, uses labour as the only input factor. The analysis of Baumol could be divided into 
two scenarios along the high of price elasticities of demand. First, assuming that the real income in the "progressive" sector increases due to output per man hour, the wage costs per unit could be held constant there, i.e. labour prices correspond to productivity. In the long run, buying goods and services from both sectors from workers from the first and second sector means real wages have to converge. Furthermore, if prices rise in proportion to costs respectively along the difference of the two productivity rates of growth of the two sectors and the demand is highly price elastic, the non-progressive sector, consisting of craftsmanship or fine restaurants, will disappear or diminish to luxury niches: customers will react with nontolerance to price increases. Thus, the first effect of different productivity growth rates leads to an increase of relative prices of services.

The second effect is linked to the assumption of low price elasticities of demand like in health care or education, supported by government subsidies as well. If full employment and no population growth are assumed, labour is a mobile factor. The relation of real output as well as final demand of the stagnant to the progressive sector remains unchanged (hypothesis of constancy of services). Ultimately, a larger share of labour force has to move to the "nonprogressive" sector as long as the amount of labour in the first sector will tend to approach zero. Thus, the share of employment in the service sector will be higher in high-income countries because of technological stagnancy and the labour-intensive nature of services. This reallocation process caused by productivity differentials could slow up aggregate growth while the relative price of services rises in the long run ("Baumol's Cost Disease"), but the output shares of the two sectors of the economy remain constant (Baumol et al., 1989, pp. 115).

In fact, Baumol's approach is a neoclassical, supply-side growth model and summed up all service categories as one. In an essay with Blackman and Wolff (1985), Baumol modifies his model by indicating "asymptotically stagnant services", using inputs from both sectors in fixed proportions admitting that "[o]utputs, firms, and industries do not fall into black and white categories of stagnancy and progressivity - they are all shades of gray" (Baumol, Blackman, Wolff, 1985: 807). Furthermore, relatively stagnant sectors could undergo a technological change supported mainly by innovation processes.

Nevertheless, the hypothesis of services being "cost diseased" was criticized in different ways. First, these results are possible, since Baumol assumes inter alia that the demand for services is independent of income. This last assumption was criticized by theoreticians who emphasize the demand side explanation of structural change which shows not a bias against services but a bias in household preferences towards services. As a result of this, the growth and the shift of the necessities related to the final demand will be derived at least from a process of income rising. This could be explained by Engel's Law and the hierarchy of needs hypothesis, assuming a dynamic model including innovation activities. The utility-based explanation could be observed on the differentiation between advanced and developing countries according to the empirical observation that income demand elasticities, and thus the expenditures and relative prices for services, would increase more than proportionally. The final demand for services is, therefore, mainly income elastic respectively non-homothetic preferences are assumed (see e.g. Pasinetti, 1981, Gundlach, 1994).

Furthermore, it is argued that the approach of Baumol just focused on consumer services, which cannot be easily standardized by mass production methods. But there are services which are impersonal, i.e. "technologically progressive", and show similar characteristics to manufacturing. Triplett and Bosworth (2003) proved in their essay that "[...]'Baumol's 
Disease has been cured" by measuring an increasing growth rate of labour productivity in service sectors at the end of the 1990s. In general, measuring productivity growth in services is difficult and leads to an under-estimation of growth. The main lack is the non-observance of the potentials of information and communication technologies (ICTs) including declining transaction costs (Wölfl, 2003). ${ }^{1}$ This means that while Baumol focuses just on consumer services to describe the potentials of this sector for economic development, it is necessary to introduce a breakdown of it, describing the main characteristics and differences. Besides the functional division of services according to the skill structures, the sectoral typology divided the service sector into four sub-sectors according to Elfring (1989) with different levels of productivity growth: producer ${ }^{2}$, distributive ${ }^{3}$, personal ${ }^{4}$ and social ${ }^{5}$ services. The first two categories could enhance productivity gains. In the case of producer services, this can be explained by their linkage to the manufacturing sector with the possibilities of externalities in their use, including indirect knowledge spillovers. Within the distributive service sectors, the productivity gains are primarily interpreted as a result of the incorporation of ICTs. In the future, although exposed to international competition, great growth potentials are expected while increasing cross-border services. On the contrary, personal and social services indicate weak or even negative potentials for productivity growth with the difficulty in their measurement. Although these services are also affected by ICTs such as aviation passenger and hotel reservation information services or the implementation in medical processes, they are typically relatively labour intensive, mainly based on client care and product quality. Furthermore, they depend on demand patterns through the welfare states regime, the demographic trends (life expectancy and birth rates) as well as the growth of GDP.

In fact, the description of services as un-productive per se is not adequate. Summing up these critical distinctions, it could be concluded that "at the end of the day, it remains difficult to determine the net result." (Nordhaus, 2008, p.1). But modelling economic growth as an endogenous process, the conclusion that the growth rate tends to zero is not right. Indeed, productivity growth potentials in services exist, as well as if productivity growth in services is less than the difference between productivity growths in the two sectors, overall economic growth decreases towards a positive rate, but it is not zero. Furthermore, despite low innovation potentials, learning processes promote the creation of one's own innovations through research and development efforts.

What about tourism services? They could be assumed under the personal services category and despite the above mentioned limitation, international tourism in less developed countries has become an attractive option for economic development. In general, the tourism sector offers for low and middle income countries the provision of hard currency to finance the importation of capital goods, increasing tax revenue, and the national income by linkage effects to other sectors. It also improves the balance of payments and employment situation by offering full-time, part-time and temporary jobs, especially for women. But through the previous description and according to a Panel Data Analysis of Sequeira and Campos (2005), tourism could only promote economic growth with some time-lag, i.e. that the long-term

\footnotetext{
${ }^{1}$ In literature this phenomenon is known as the productivity paradox according to Solow, whereby direct and indirect network externalities, spillover effects as well as new service sectors and products like IT investments and the contributions of IT to product quality, variety, and customer service are not involved in standard productivity measures.

${ }^{2}$ Financial, insurance and real estate services.

${ }^{3}$ Retail and wholesale trade, transport services and communications.

${ }^{4}$ Hotels and restaurants, domestic, repair, recreational and cultural services.

${ }^{5}$ Government services proper (civil and military), health, educational and miscellaneous social services.
} 
development should not be based on tourism but on general development. In other words, this sector could be stated merely as a driver and supporter of economic development.

Thus, before having a brief look on one country case and its tourism potential and performance, the question of which conditions and determinants could enhance these intersectoral shifts, should be answered. Thereby it is necessary to analyse the main characteristics of tourism services along the "social capabilities" and further demand and supply side implications, including how far innovation potentials of tourism services could be expected.

\subsection{The main potential of the tourism sector for economic development}

Structural change is connected with adjustment costs, while changes in the occupational and skill structure of labour demand and supply influence the production level and growth potential of an economy. Thus, specific knowledge and skills are becoming obsolete. In addition to this, a pro-active government intervention in the empowerment of disadvantaged segments of populations is essential during this process, but also the creation of favourable conditions for doing business, in order to encourage local enterprise formulation and Foreign Direct Investment (FDI). In which sectors there is a need for promotion for sustainable economic growth, through enhancement of $\mathrm{R} \& \mathrm{D}$ and government demand for special consumer goods, is often the question. These two implications describe the "social capabilities" which could be divided into two component groups: human capital and institutional arrangements. In this context, they could be observed as supply factors of tourism.

Knowledge and the so-called "knowledge economy" became the most competitive factors in the twentieth century with human resources and skills on the field of technical, ICTs, communication, analytical and team work (Castells, Aoyama, 1994). Human capital ${ }^{6}$ could be $^{-}$ described as a production factor and the sum of skills and capabilities of the educated people, including the quality of the educational system, investments in education and enrolment rates. It assumes that the state and structure of education embodied in the population should be in a position of easily embracing foreign technology and rapidly developing its own. Unemployed people could raise their level of employability by education and re-qualification to avoid mismatch, but also the danger of de-qualification through long-term unemployment. It is an intangible and (almost) immeasurable asset while developing human capital resembles a threshold effect - it is necessary, but not sufficient to secure labour force competitiveness. According to Pugno (2006), services like education, health and cultural services contribute to human capital formation and therefore, promote growth, in opposition to the negative Baumol effect on growth. Also Sequeira and Campos (2005) emphasize that the tourism sector acts as a demanding sector for human capital accumulation. But although this sector is rather labourintensive with low productivity growth, it contributes to solving labour market problems by augmenting the job creation potential for unskilled and semi-skilled workers. But if work arrangements are mainly part-time and seasonal, there are limited career opportunities and intention to invest in education and training, including often paying minimum wages.

\footnotetext{
${ }^{6}$ The human capital theory along Becker (1964) emphasizes the role of schooling as an investment in skills and therefore augmenting worker productivity. The learning-by-doing concept of Arrow (1962) as well as Lucas (1988) makes also clear that the enhancement of human capital contributes to an increased productivity whereby the equipment of human capital as well as sector-specific learning effects determine the sectoral production structure.
} 
In addition, there are institutional arrangements such as "the attributes and qualities of people and organizations that influence the responses of people to economic opportunity, yet originate in social and political institutions" (Temple, Johnson, 1998, p. 966). Here the emphasis is placed on cultural and religious traditions, as well as on political and monetary terms, which decide the general conditions for a rapid diffusion of knowledge, spill-over effects, externalities and investments. This factor includes a well functioning capital market that attracts foreign investors, technology transfer and international technological networks, as well as secures the conditions for small and medium enterprises (SMEs) and selfemployment. Concerning the tourism sector, the government itself has to support it by offering subsidies and institutional assistance programs for tourism destination development and providing and maintaining the required infrastructure ${ }^{7}$, the latter being often of specific use for the tourism sector. In general, this sector is a demand-pull one, extremely volatile and sensitive to business cycle development in the country of the guests. For example, according to Mervar and Payne (2007), the long-run elasticity estimates for Croatia, as a highly specialized tourism-related country, show that tourism demand is positive and highly elastic with respect to the income of tourist-generating countries and was adversely affected by the political situation in the 1990s. Mihaljek (2005) also points to the fact that tourist behaviour is highly volatile and sensitive to social influences like fashion, and short-term reactions. Consequently, it should not be overlooked that the future economic growth path depends on the development of a manufacturing sector including business and distribution services with their linkage effects. Furthermore, despite the conclusion drawn by Cazes, Nesporova (2007) about the possibility of international retail, catering and hotel chains squeezing out small local firms and often relying on their own suppliers from abroad, MNCs could offer an enlarged scope of services to tourism consumers at competitive prices. This would include also fixed capacity and costs by exploiting EOS.

In general, the productivity level in tourism is rather low, not least because the tourism sector "differs from other products in that it cannot be examined prior to purchase, cannot be stored and involves an element of travel" (Sinclair, 1998, p. 14). But this sector has a lot of forward and backward linkages, with large and intensive potential for multiplier and spill-over effects on the rest of the economy including the agriculture and manufacturing sector, as well as services like banking and insurance, retail trade or public sector services. Sinclair (1998) describes the tourism sector as "a composite product, involving transport, accommodation, catering, entertainments, natural resources and other facilities and services such as shops and currency exchange. [...] It is useful to examine it not as an industry per se but as a collection of interrelated industries and markets located in both industrialised and developing countries" (Sinclair, 1998, p.14).

Hence, why should an economy specialize in tourism if there are minor prospects for this sector to be a source of structural change and growth for the whole economy? Thus, the main question is how to identify determinants of structural change and thus innovation potentials in the sector itself which contribute to growth and development. So far, where could innovation potentials in the tourism sector be identified? In general, innovation in services should be defined along the terminology of Schumpeter (1934) as the improvement of existing and the introduction of new services, as well as the opening of a new market. According to Weiermair (2006) and Keller (2006), this could be translated in the tourism sector on the one hand as innovations that could reduce costs by changes in production processes and the creation of new transaction channels, structures and means mainly by ICT based innovations in

\footnotetext{
${ }^{7}$ Including airports, road and public transport systems, environment protection related projects, energy, water supply and sanitation, among others.
} 
distribution and marketing (e-tourism). Through the characteristic of the tourism product as "a bundle", new "bundles" have to be created and different suppliers are needed to create the tourism "as an experience" mainly in the field technology, distribution and human resources sharing. In the field of vertical co-operative tourism marketing, new forms of network organisation and customer advisory services emerged to extend markets, product line extension by branding policies, changing cost (price)/quality ratio of the product.

To examine the main innovation potentials of this sector, first it is necessary to divide the tourism product into homogenous and heterogeneous components and combine the results of the previous chapters of this essay (see figure 1).

\section{Figure 1: The tourism product}

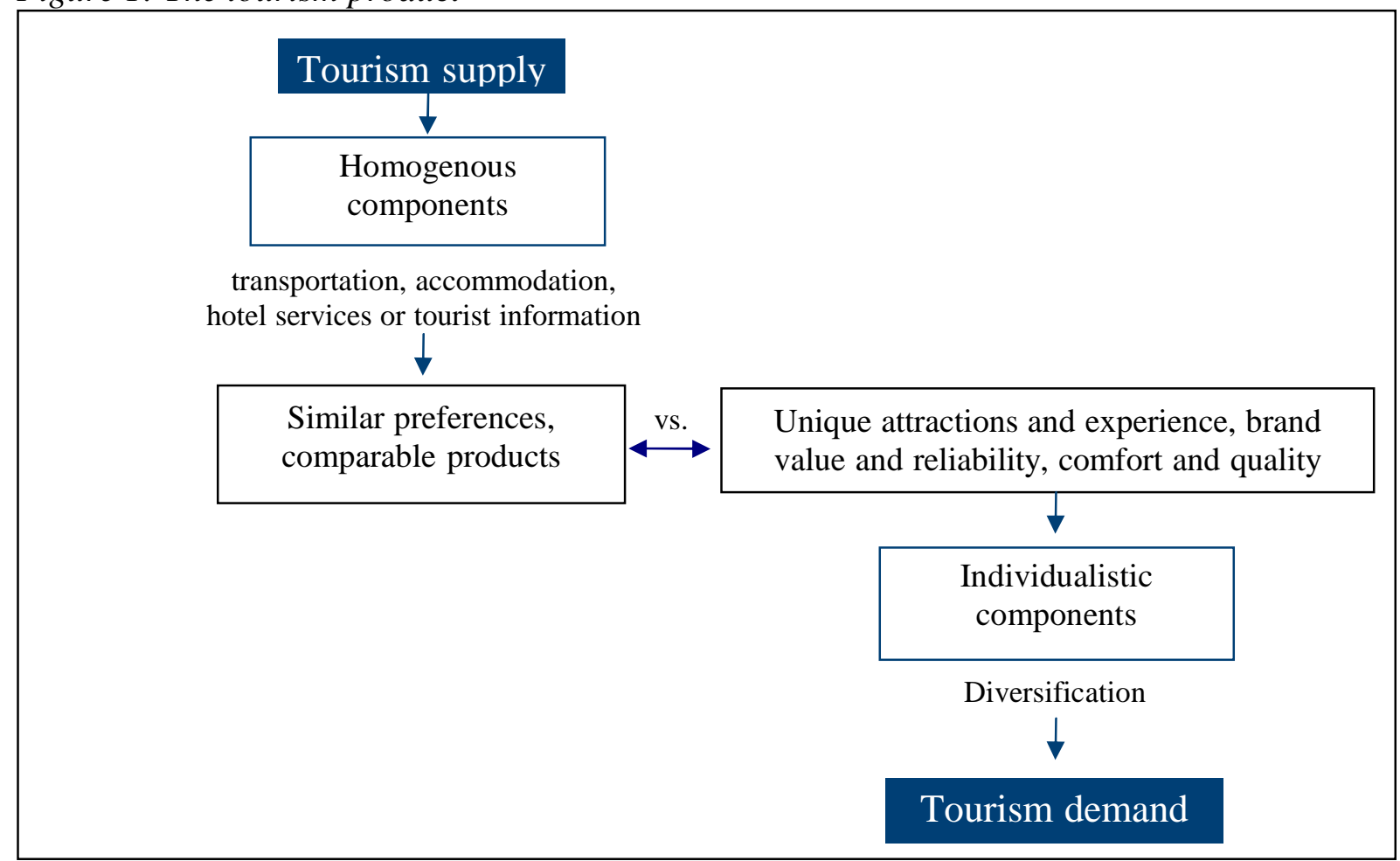

Source: Own illustration

At first, tourism supply offers more homogenous components like transportation, accommodation, hotel services or tourist information which are more or less similar in all countries. Due to the development of ICTs, tourism supply becomes increasingly transparent worldwide, enforcing global competition by pressure on quality. The international tourism environment is vast. Companies involved in the tourism business must change and adapt their strategic development plan to respect the movements on the global tourism market more than companies involved in other sectors. But competitiveness in tourism encompasses also price differentials coupled with exchange rate movements. Thus, according to Sinclair (1998), there is a danger since the prices of non-traded goods and services consumed by tourists could increase. Therefore, a modification of domestic consumption patterns is possible having an inflationary effect on the host country. Another risk is related to the fact that earnings from the tourism sector are unstable over time because of relatively high elasticities of demand with respect to changes in inflation, exchange rates or political instability.

On the other hand, tourism services must have an individualistic component which could also be observed in the fact that international tourism shows a shift from mass to more 
individualistic and flexible forms of tourism demands. According to that, the major promoters of innovation are the customers. This involves product changes, providing a diversification into more varied tourism experiences for a "new customer". Trends like the current shift in the population pyramid, individualization, or working versus leisure time, lead to a local competitive advantage involved with the nature of tourism services, whereby they have to be delivered locally to the consumer in tourism destinations. Tour operators and travel agents provide an individualistic offer built on the strengths of a destination, including the natural and cultural specifics as well as local forms of entertainment, all envisioned within the concept of "sustainable tourism". Consequently, not only should the interchangeable "sun and sea" product be considered, as the tourism sector needs diversification and adjustment to demand. Products with a non seasonal character and value added (e.g. business, cultural, nautical, agro- or eco-tourism, including national parks, thermal spas, mountains etc), should be further implemented and expanded in the tourism offer (Javor, 2005). Innovation is much more limited in SMEs than in MNCs because of the lack of networking, but they could serve as a niche segment, offering specific opportunities for a very narrow segment of demand.

Finally, summing up both innovation forms, the main competitive potential is linked to the quality of human capital (Algieri, 2006). Due to the character of the tourism sector being like a bundle of services, this not only leads to the formation of various types of skilled labour like organisational, interactive and managerial skills, but also experts for market research and promotion. Education is a necessary condition for the potential employment of local people with needed particular knowledge such as communication, catering, languages and intercultural skills. For enforcing such developments, it is necessary to enlarge the durability of the working contracts. Jobs being temporary could not enhance the rise of the human capital quality. Within MNCs, it is also necessary that a transfer of specialist knowledge of the foreign participants involves domestic labour, employees and managers, in the process of learning and upgrading their skills, which represents a considerable spill-over effect for the domestic economy and depends on the interrelationships between other sectors.

\subsection{Tourism and its contribution to economic growth: a survey of the literature}

So far, institutional stakeholders (that is to say, some of the principal international organizations and institutions) distinctly agree with the positive implications that tourism could bring for the economic growth of a nation. The latter is measured in terms of GDP contribution, employment generation, FDI and earnings, among many other criteria. Altogether, tourism is hitherto optimistically envisioned when it comes to its encouragement of economic growth.

In this context, Cortés-Jiménez (2008) emphasizes tourism's contribution to employment, as well as its positive aspects in terms of the attraction of investments and foreign capital. Using dynamic panel data techniques and applying them to the cases of Spain and Italy, the author supports the idea that tourism, if "well oriented", can play an important role for economic growth. The results reveal that both international and domestic tourism play a significant and positive role for regional economic growth in Spain and Italy, although the pattern of these effects differs among different types of regions. Based on the latter, it is stated that developing nations should envision tourism as an activity that could support growth and development. This is reinforced by the idea that tourism is one of the economic activities with 
a higher capacity to generate employment and to attract investments and foreign capital, as well as its generation of direct, indirect and induced effects in the local economy.

Copeland (1991) analyzes the economic effects of an increase in tourism in a small, open economy, using a general equilibrium international trade model. He comes to the conclusion that an increase in foreign tourism will increase welfare only through its effects on the price of non-tradables, if taxation, distortions and foreign ownership are not present. In other words, he affirms that an increase in tourism improves welfare only if it induces an increase in the price of non-tradable goods: this would imply a direct effect on the country's real exchange rate (i.e. the price of services relative to tradables), and hence on welfare. The fact that factor mobility and foreign ownership tend to reduce the gains from tourism, while commodity taxes tend to increase them, is also mentioned. Another important aspect stated concerning tourism is related to its nature, namely, that "the bundle of goods and services purchased by a tourist is consumed jointly with unpriced natural amenities, such as climate and scenery" (Copeland, 1991, p. 516). As will be analyzed in a later section of this paper, the latter concept should be carefully considered by Colombian policy-makers, when implementing some strategies - especially in the field of ecotourism. Up to now, the strategy of the government for attracting tourists to the country has been strongly based on improved national security conditions, as well as on some tax exemptions that have been offered specially to foreign tourists. As a result, the problem of "unpriced natural amenities" as Copeland defines it, can be clearly identified in Colombia.

Therefore, Copeland affirms that the benefits associated with foreign tourism will be directly linked to the amount of income which is repatriated to foreigners. And he even proposes that the value of the returns accruable to foreigners can be that significant that in some situations, tourism tends to be welfare decreasing.

The observations made by Copeland regarding taxes and FDI should be of paramount interest at the moment of evaluating the strategies pursued by Colombian policy-makers, in order to promote and encourage tourism exports and at the same time, guarantee the desired economic and social positive effects for the population. As he points out, there are even some cases where tax revenues are likely to be the major source of benefits from tourism, since they "provide a method for extracting rents from tourists for the services of the unpriced natural amenities that they consume" (Copeland, 1991, 522). Finally, Copeland also warns about the possibility of some negative effects of tourism, when it comes to income distribution and a possible "de-industrialization": it is therefore of the greatest importance to envision the benefits of tourism as necessary for the whole economy and the importance of the linkages between the sectors directly and indirectly influenced.

Recurring to a computable general equilibrium model, Blake (2000) conducts a study with the objective of analyzing the economic impact of tourism in Spain. One interesting finding is linked to the capital intensity of tourism in that country, which is superior to its exports, and "even more when all intermediate goods are included" (Blake, 2000, p. 10). And in the same direction as Copeland, another important argument is related to the fact that eventually an appreciation of the real exchange rate could lead to a decrease in other exports and to the increase of imports. Again, arguments are exposed in favor of tourism taxation, for the sake of environmental protection and tourism sustainability. The argumentation towards a direct stimulation of tourism-related sectors (such as air transport, restaurants and hotels) an indirect impulse to others (e.g. clothing and food), and the possible decay of the traditional exports derived from adverse exchange rate effects, is also supported. 
Brida et al. (2007) point out that an increase in tourism modifies the composition of economic activities. This impact would be structural since a major reallocation of resources between activities, but also between private and public uses, takes place. By comparing two different groups of countries (established destinations and some emerging tourism destinations), it is shown that the tourism contribution to GDP is higher for the first group but it is not necessarily associated with a greater contribution to the economy's growth.

All in all, tourism implies both advantages and disadvantages when considered as a probable driver of economic growth. The Colombian case depicts how a country that has traditionally given low priority to tourism has been lately demonstrating positive economic effects in terms of investments, employment, exports and growth. But at the same time, it illustrates how some of the actions and strategies implemented by the policy-makers have to be revised and fine-tuned, in order to effectively guarantee that tourism will increase the welfare of the Colombian population.

\section{The Role of Tourism within the Colombian Economy}

\subsection{Structural Change in Colombia since 1996}

At the beginning of the 1990s, a process of opening up the economy began to take place in Colombia. The import substitution approach was replaced by an export-oriented economic model, which strived to encourage national industries to face competition in the international markets. A study conducted by the Banco de la República (Colombian Central Bank) explains that the underlying objectives of this strategy were to accomplish a remarkable increase in productivity levels, to significantly boost investment in technology and to promote a reallocation of the production (Villar, 2000). The analysis of the role that services play for the Colombian economy is supported in some statistics provided by the World Bank, collected for the period 1996-2006.

It is noteworthy to point out that the Colombian GDP composition by sector has experienced some noticeable changes within the last 12 years. Between 1996 and 2000, the percentage of value added by agriculture to the national GDP oscillated in an interval of values equal or near to $14 \%$. From that year onwards, it is possible to identify a drop in the share of agriculture, going down to a percentage of $12.1 \%$ by the year 2006 (see Figure 2). Another interesting trend may be observed, namely the increase in participation by the service sector. The industrial sector has also lost some points from its former level at the beginning of the decade: while in 1990 its share was of $37.9 \%$, it went down to $31 \%$ in 1996 , recovering some points since 2003 . 


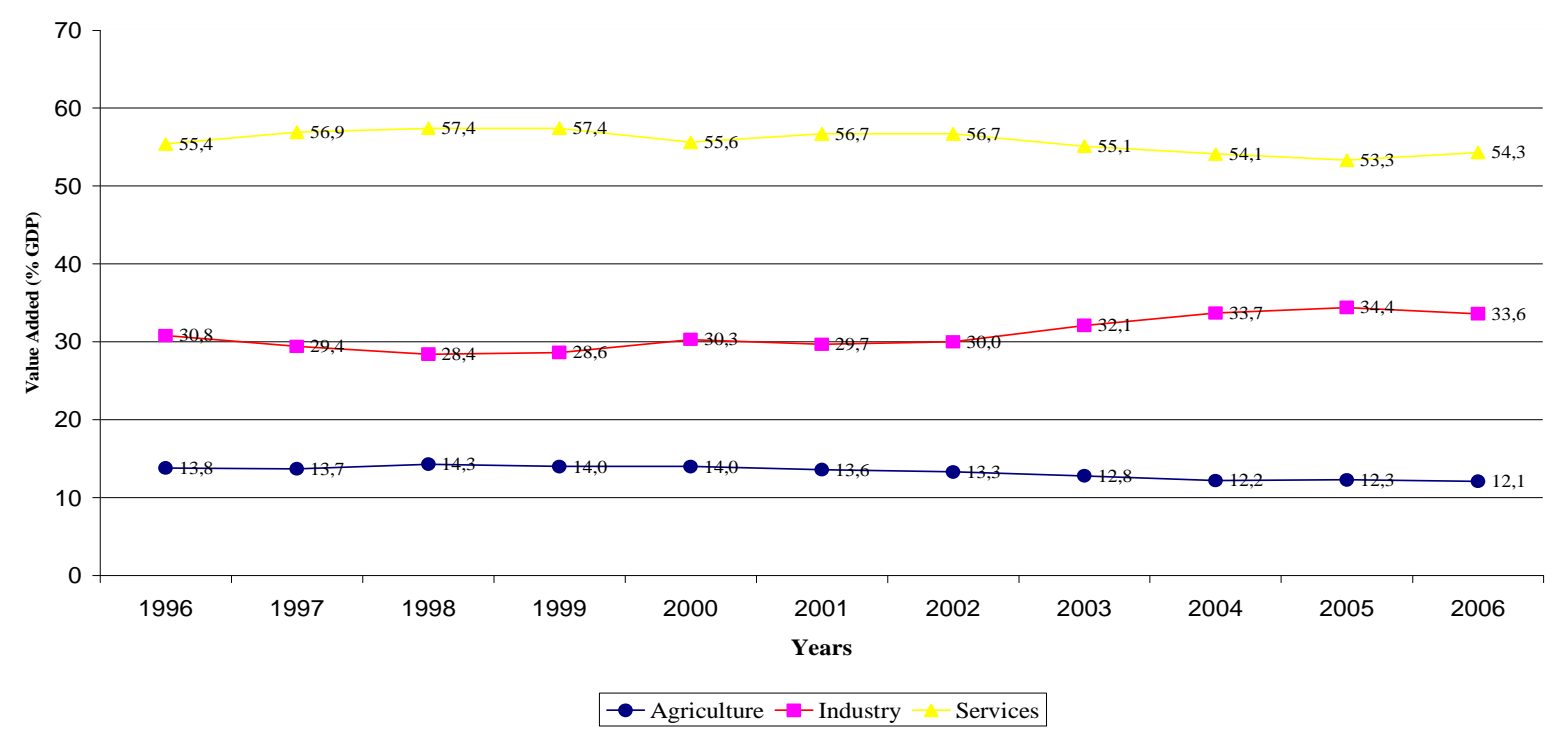

Source: The World Bank Group, World Development Indicators Database

The above depicted trends allow us to appreciate that there has been an economic transformation within the period of time analyzed, as in the same direction of many developing countries, where the service sector shows an increasing participation within the national economy. However, the industrial sector continues to occupy a relevant position in Colombia, while the participation of agriculture began a path of constant decrease since the year 2000.

Within the service sector, some branches have gained an increasing importance for the generation both of income and employment at national level during recent years, e.g. tourism, managerial services, construction, communications, financial services and informatics (http://www.mincomercio.gov.co/eContent/newsdetail.asp?id=5393\&idcompany=1, 2006). For the whole period of time analyzed, it is possible to observe how travel and tourism have represented the most important component of service exports in Colombia. In 2007, this participation within the total amount of services exported came to a figure of $76 \%$. Since 2005, managerial and construction services have established themselves as the second most important source of foreign earnings within the export of services, representing $10 \%$ of the total in 2007. Also since 2005, communication and information services have occupied the third position in terms of its participation within the whole amount of services exported, "other services" the fourth and insurance and financial services the fifth (with shares of 8.4 and $2 \%$ respectively). This is graphically illustrated in figure 3. 
Figure 3: Share of Total Foreign Services Sales by Sector in Colombia, 1996-2007

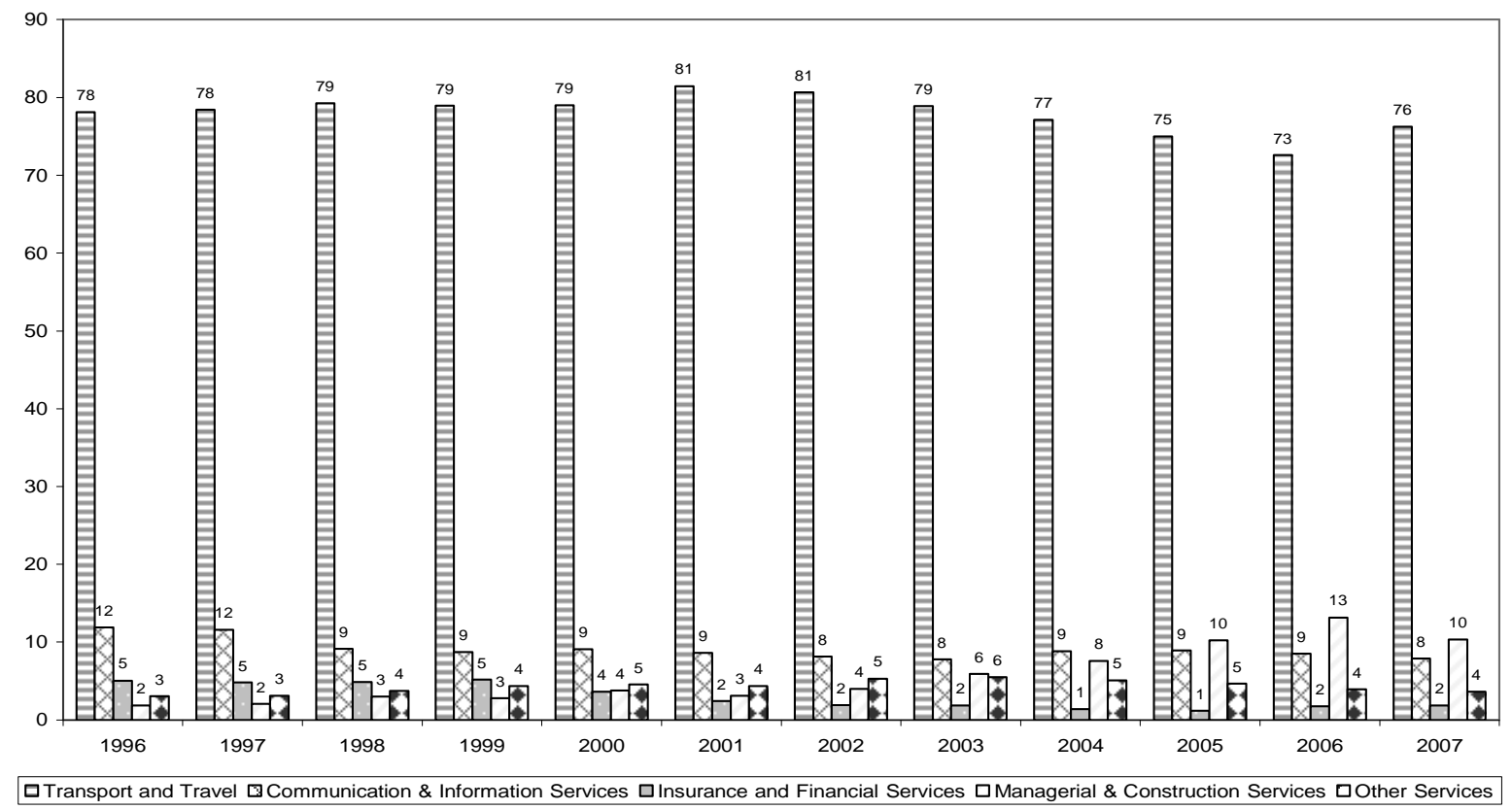

Source: Colombian National Central Bank

As for the importance of tourism for the generation of foreign currency in Colombia, it is noteworthy to point out that if just the service exports are considered, the share of the earnings generated by the travel and tourism accounts represents more than $70 \%$ of the total amount received in the country. This is depicted in the following graphic.

Figure 4: Services Exports by Sector in Colombia, US \$ Million, 1996-2007

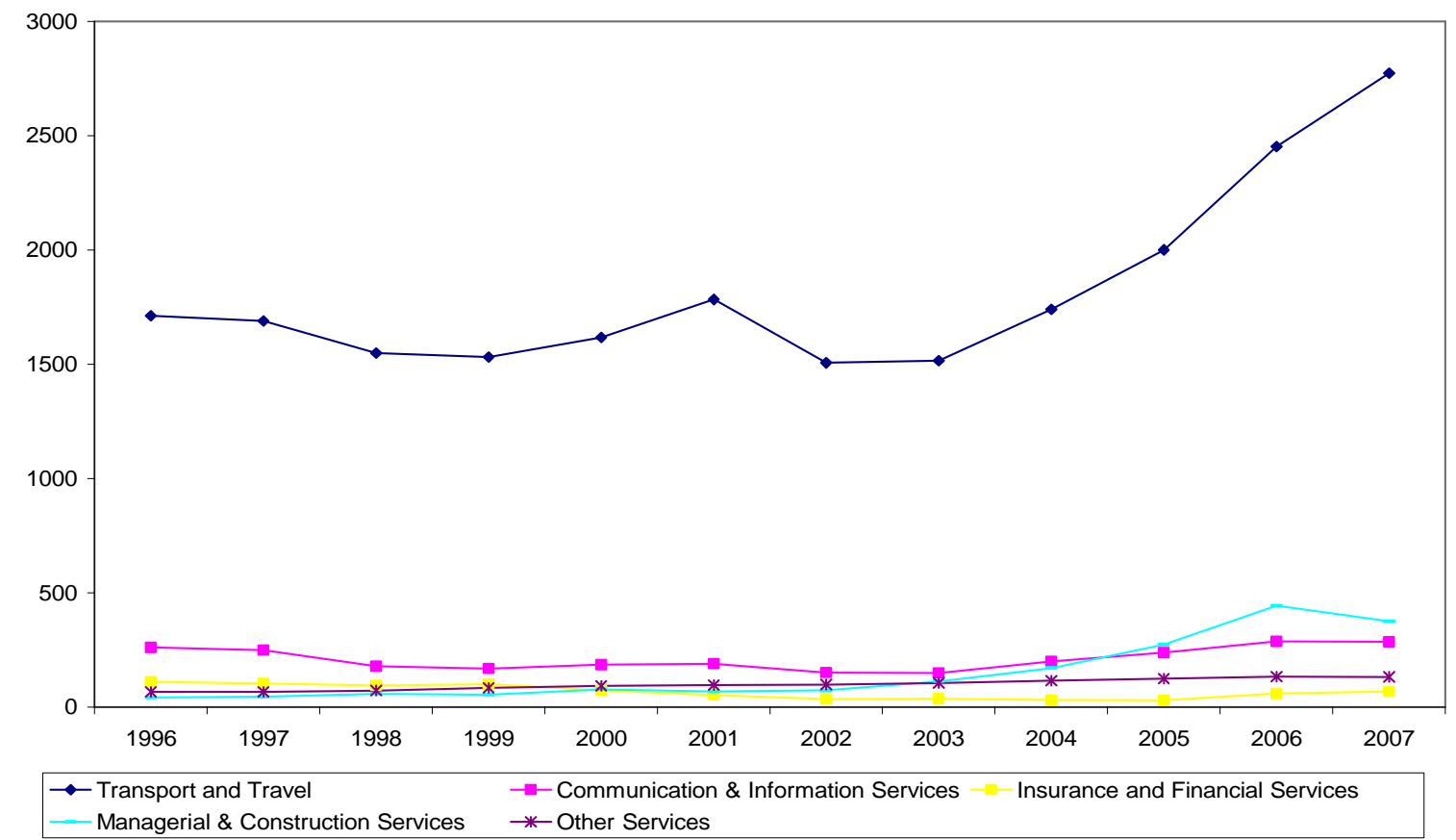

Source: Colombian National Central Bank 
Taking into account this perspective, it is unquestionable that this economic activity represents an important source of foreign currency. Besides this, it should be mentioned that earnings proceeding from travel and tourism have registered important values since 2003 . Comparing the years 2001 and 2007, revenues have increased by 55\%.

When it comes to analyzing the behavior of the "travel and tourism" account, it is important to appreciate how sensible these earnings have been to the domestic security conditions in the country: since 1997, they showed a tendency of constant decline, a process briefly interrupted in 2000 and 2001, to decrease again in a very impressive $16 \%$ by the year 2002. Since the current Colombian administration took office at the end of the same year, a very striking recovery of the same account can be observed, as depicted by the graphic. Positive variations have been registered since $2003(0.7 \%, 14.8 \%, 15 \%, 22.6 \%$ and $13.1 \%$ respectively).

This trend is clearly traceable to the so-called "democratic security policy" that has been implemented during the last six years. As is widely known, a widespread perception of safety and security in any country in the world is very important for tourism to boom, which is exactly what happened in Colombia, since the improved safety conditions have implied a surge in domestic tourism and a remarkable increase in foreign tourists arriving to the country. Despite the unquestionable accomplishments of the Colombian administration since 2003 in terms of safety and security conditions, undoubtedly the country faces a daunting challenge to guarantee that these conditions will be maintained in the future. In addition to this, it is interesting to notice that within the World Economic Forum's Travel and Tourism Competitiveness Index, this is precisely one of the criteria where Colombia scores the worse, occupying $118^{\text {th }}$ position out of 130 countries analyzed (WEF, 2008, p. 154). This is clearly a factor that has already been tackled by Colombian policy-makers and will be of paramount importance in the future, as well.

The very important rebound of tourism in Colombia can also be appreciated by taking a look at data concerning the arrival of foreign tourists to the country, which have more than doubled within the last eight years:

Figure 5: Number of Arrivals of Foreign Tourists to Colombia, Terrestrial and Aerial, Thousands, 2000-2008

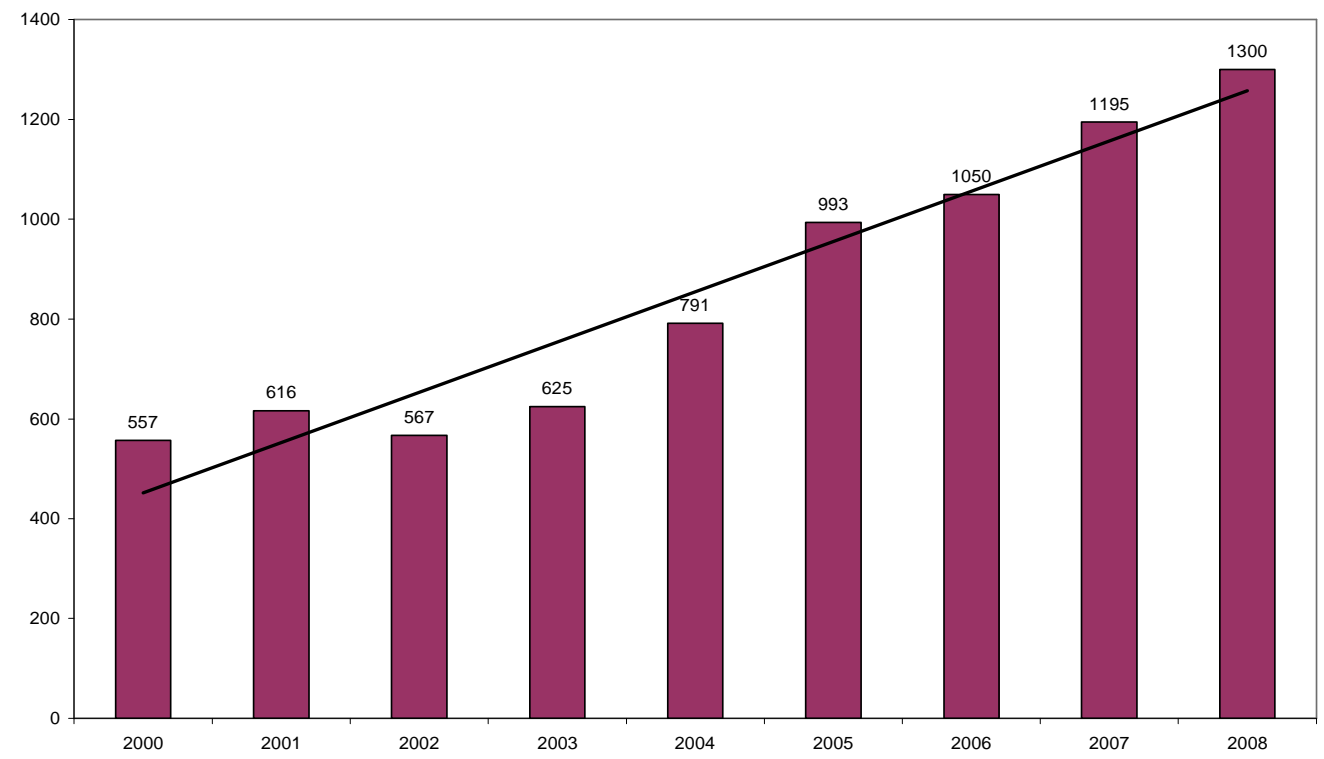

Source: Colombian Security Department 
However, up to this point the analysis of the importance of tourism in Colombia in terms of foreign currency should be complemented by the analysis of the share that this economic activity has within the total amount of Colombian exports. This would allow to establish if effectively, as expressed by Sinclair, tourism is becoming a risky option for a developing country such as Colombia, and if the nation is strongly dependent on this economic activity.

For accounting purposes, the Colombian National Central Bank groups exports among the following: traditional (comprising coffee, oil and its derivatives, coal and nickel), nontraditional (flowers, emeralds, minerals such as gold, and a big variety of agro-industrial and industrial products) and services (transport, travel, communication and information services, insurance and financial services, managerial and construction services, other services). A couple of interesting trends can be identified within the period of time comprised between 1996 and 2007:

- Traditionally, the most important source of foreign currency for Colombia has been represented by the export of traditional products, especially coffee, oil and coal.

- Since the year 2001 a "tipping point" can be observed, that is, that the share of nontraditional exports starts to surpass the participation of the traditional ones, within the total amount of foreign sales. This is a remarkable fact that responds to a strategy of the latest Colombian governments and the Ministry of Commerce, Industry and Tourism, oriented towards the diversification both of the composition and destiny of foreign markets, an initiative supported by the process of opening-up the economy. The most important sectors within the so-called "non-traditional exports" are comprised of light industry and manufactures, basic industry, agro-industrial and mining products.

- While non-traditional exports generated $46 \%$ of the total foreign currency earnings during the last year, traditional exports represented $43 \%$ of the same incomes. Services accounted for a share of $11 \%$. This is a trend that has been stable since 2001 , as mentioned before.

- The share of the earnings originated in the travel and tourism accounts within the balance of payments represents $8 \%$ of the total amount of foreign currency incomes. This is an important figure: while it is true that Colombia is not in a situation of overdependence on tourism earnings, it has undeniably become an important source of income. Tourism is now the third most important export for the country, after oil and coal, according to the Colombian National Central Bank. 
Figure 6: Colombian Exports by Sector, US \$ Million, 1996-2007

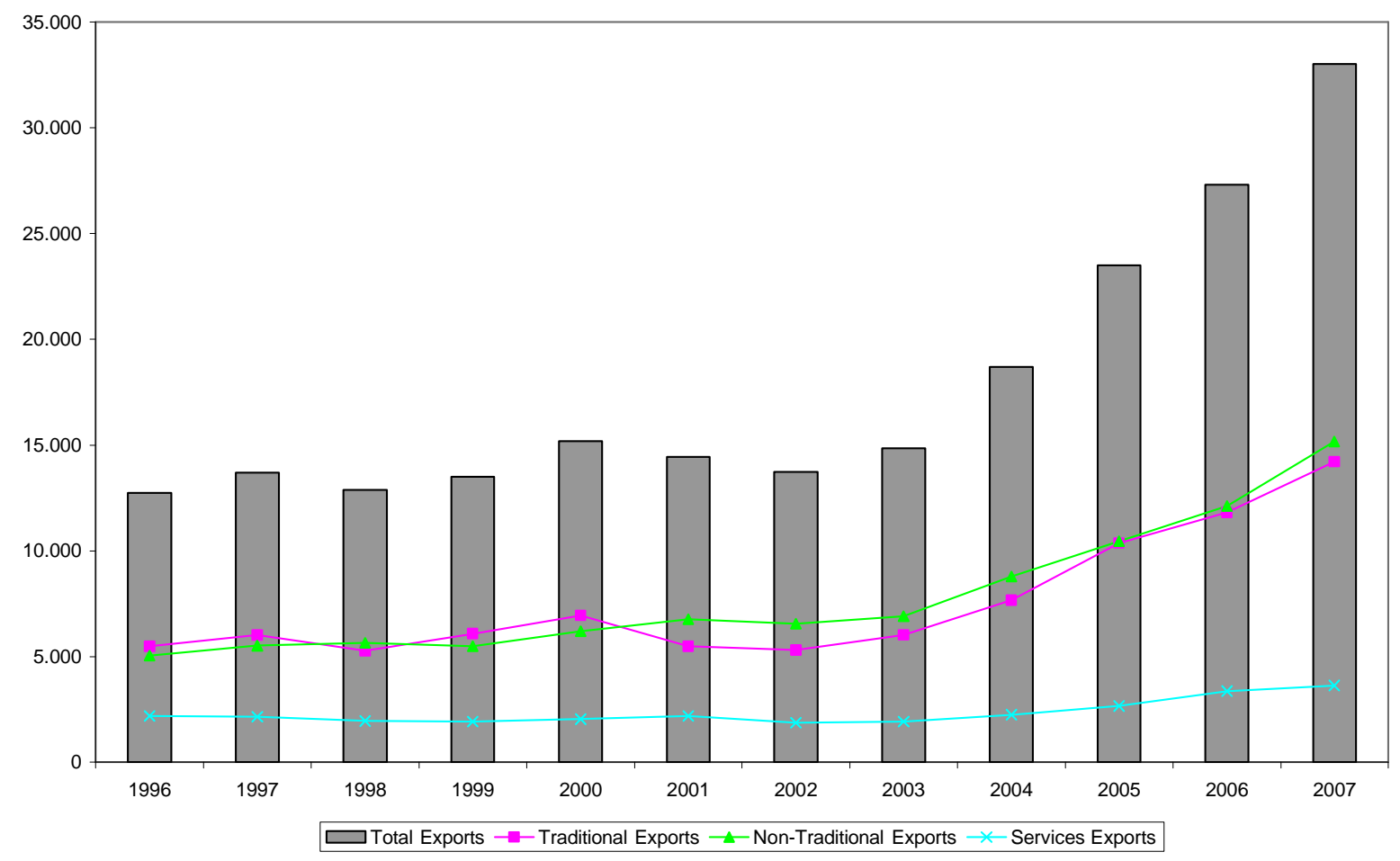

Source: Colombian National Central Bank

In contrast, a very interesting finding can be identified when the foreign currency originating in the travel and transport account is analyzed with respect to the total value of exports registered in the balance of payments. While it is true that the importance of tourism in Colombia has been growing during recent years, conversely, its share in terms of foreign currency generation has been decreasing: since 2001, this value has been experiencing a path of constant decrease, 2006 being an exception when this participation slightly increased, to continue its path of decline in 2007. This can be explained by the very significant role that both traditional as well as non-traditional exports play within the Colombian economy (see figure 7). 
Figure 7: Share of the Travel and Tourism Account on the Total Value of Colombian Exports, 1996-2007

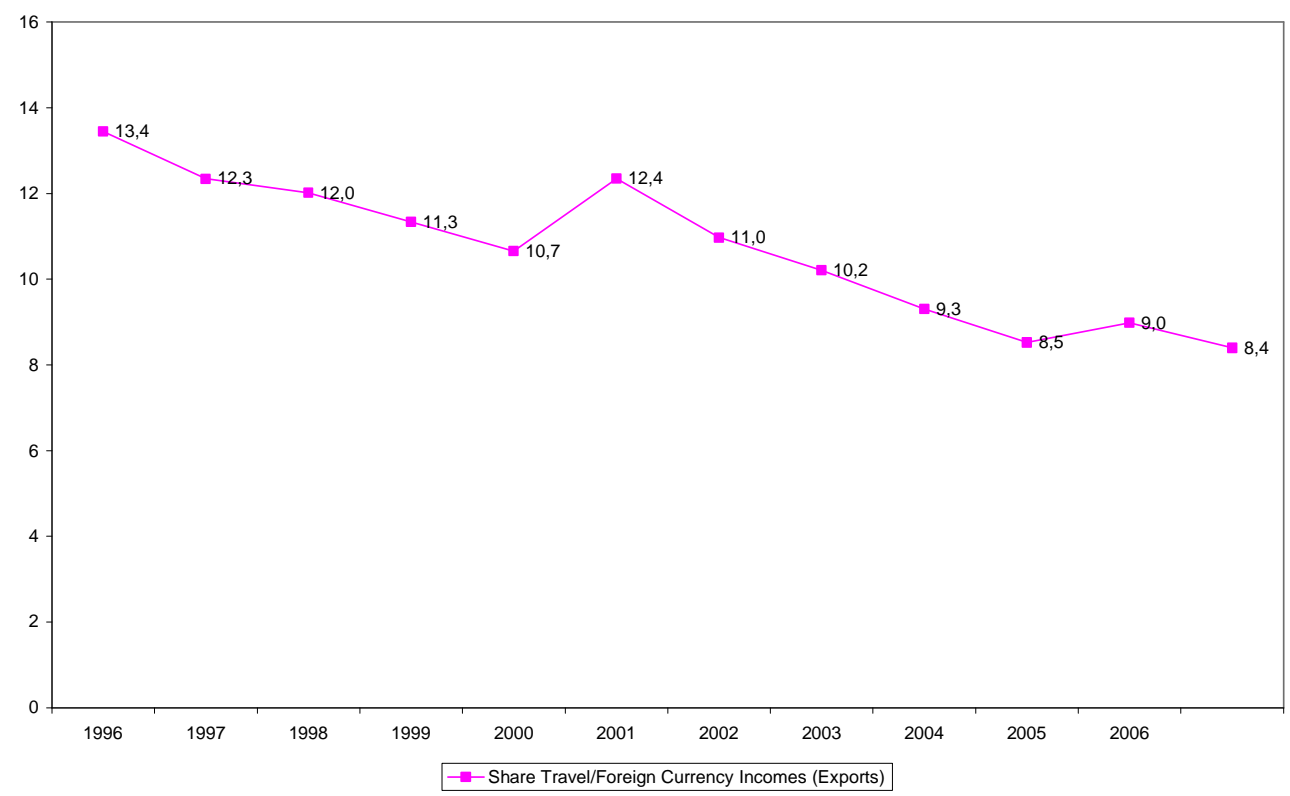

Source: Colombian National Central Bank

Furthermore, it is relevant to analyze the width and depth of the tourism sector within the Colombian economy, taking into account other indicators that may show in a clearer way its full impact.

\subsection{How Big and Representative is the Tourism Sector in Colombia?}

As stated by the World Tourism Organization (UNWTO, 2008), Colombia has been consolidating its position in the international leisure and business tourism markets since 2002 . This can be explained by different factors, such as the great effort the government has undertaken to promote tourism as an important non-traditional export, the increased security and stability conditions, the significant role that the Ministry of Commerce, Industry and Tourism and Proexport (being the main Colombian Business Support Organization) have played and in general terms, the change of attitude towards an economic activity that has not traditionally been seen as an important driver of economic growth in the country.

Despite the undeniable wealth of the nation in terms of biodiversity ${ }^{8}$ and its important endowment in terms of natural resources, as well as its privileged geographical location in South America - with five different natural regions that present their own unique characteristics, tourism in Colombia has played, until now, a limited role within national development strategies.

The most recent objectives in Colombia concerning the tourism sector have been clearly defined by the so-called "Sectoral Tourism Plan 2007-2010", which introduces seven strategies to be followed to encourage this economic activity, namely: the improvement of the

\footnotetext{
${ }^{8}$ The Natural Resources Defense Council in the U.S. defines biodiversity as "a large number and wide range of species of animals, plants, fungi, and microorganisms. Ecologically, wide biodiversity is conducive to the development of all species". According to the International Union for Conservation of Nature (IUCN), when it comes to international standards, Colombia occupies the second position in the world, after Brazil.
} 
industry's competitiveness (which is currently being measured by international recognized standards, such as the World Economic Forum's Travel and Tourism Competitiveness Index TTCI), the enhancement of the tourism infrastructure, the strengthening of the country's promotion and "image-building" process, the introduction of a system of tourism-related information (consolidation of the TSA methodology system, for estimating the full impact on tourism on the economy), the introduction of better aerial connections between the different Colombian regions, the encouragement of both tourism supply and demand and finally, the accomplishment of a higher level quality of education and through these means, the generation of a "culture of tourism" (Mincomercio, 2008).

Another important initiative undertaken by the tourism authorities and policy-makers in Colombia has to do with trying to manage the effects that one of the structural characteristics of tourism -seasonality- could have for the incomes derived from it. For countering that, Colombian policy-makers have defined a strategy of concentrating the offer in four specific products, besides the typical "sun and sea", ecotourism, cultural tourism, health tourism and business tourism. The underlying motivation is to broaden the offer of the traditional "sun and sea" product.

The World Travel and Tourism Council - WTTC together with UK-based Oxford Economics, have leaded an initiative to introduce a system of Tourism Satellite Accounting research, which currently covers 176 economies around the world. As stated by the WTTC, using a combination of macro-economic research and forecasts, national accounting data/information, travel and tourism variables and econometric modeling, a system of research covering all concepts of travel and tourism demand, from personal consumption to business purchases, capital investment, government spending and exports has been produced. This information is then translated into economic concepts of production, such as gross domestic product (GDP) and employment, which can be compared with other industries and the economy as a whole to provide credible statistical information that will assist in policy - and business decisionmaking (http://www.wttc.org/eng/Tourism_Research/Tourism_Satellite_Accounting/TSA_ Definitions_and_Methodology, 2007). In essence, it is a system derived from the national accounting, which intends to obtain complete and reliable information, internationally comparable, with regard to the importance of tourism within the whole economy (http://www.mincomercio.gov.co/econtent/NewsDetail.asp?ID=5043\&IDCompany=1, 2006). It follows the standardized United Nations' methodology for measurement of Travel \& Tourism's economic impact on personal consumption, business spending, capital investment, government expenditures, exports and imports, culminating in quantification of the contribution to gross domestic product and employment (WTTC, 2008a, p. 8).

Through this means, the so-called "Tourism Satellite Account" (TSA) is an important and standardized methodology that allows analyzing the real extension and depth of the effects of tourism not just towards the branches directly related, but also, for the economy as a whole. This implies an important effort directed to estimating the effects of tourism on employment, growth and earnings. Another important contribution is related to the possibility of comparing countries around the world, based on the already mentioned "standardization" that this methodology introduces.

For the particular case of Colombia, it has been possible to gather data and information concerning the TSA since 1996. It is important to mention that before this methodology was introduced, the most important data and statistics related to tourism have been produced by the Ministry of Commerce, Industry and Tourism, Proexport, the Colombian National 
Statistics Department (DANE) and the Colombian National Central Bank (Banco de la República ). Still nowadays, mostly all the information, reports and analysis elaborated by the government are strongly based on the data collected by these entities: even though these are credible and reliable sources, the information produced does not allow to perceive the full impact of tourism for the Colombian economy, these are mostly statistics dealing with tourism-related activities such as transport, restaurants and hotels.

Table 1: Satellite Account Table - Colombia, 2003-2018

\begin{tabular}{|c|c|c|c|c|c|c|c|}
\hline & 2003 & 2004 & 2005 & 2006 & 2007 E & 2008 F & 2018 F \\
\hline \multicolumn{8}{|l|}{$\begin{array}{l}\text { Travel \& } \\
\text { Tourism } \\
\text { (US\$ mn) }\end{array}$} \\
\hline $\begin{array}{l}\text { Personal } \\
\text { Travel \& } \\
\text { Tourism } \\
\end{array}$ & 2419,9 & 2838,7 & 3340,2 & 3722,8 & 4465,6 & 4808,2 & 6607 \\
\hline $\begin{array}{l}\text { Business } \\
\text { Travel \& } \\
\text { Tourism }\end{array}$ & 1322,3 & 1531,5 & 1711,4 & 1875 & 2401,8 & 2518,5 & 3489,7 \\
\hline $\begin{array}{l}\text { Visitor } \\
\text { Exports }\end{array}$ & 1191 & 1366 & 1570 & 2005 & 2180,5 & 2248,2 & 3331,1 \\
\hline $\begin{array}{l}\text { Travel \& } \\
\text { Tourism } \\
\text { Consumption } \\
\text { (US\$ mn) }\end{array}$ & 5027,9 & 5849 & 6761,1 & 7751,7 & 9232,3 & 9765,9 & 13680,2 \\
\hline $\begin{array}{l}\text { Government } \\
\text { Expenditures } \\
\text { - Collective }\end{array}$ & 217,3 & 258,80 & 319,9 & 341,1 & 423 & 437,9 & 578,9 \\
\hline $\begin{array}{l}\text { Capital } \\
\text { Investment }\end{array}$ & 1487,2 & 1660,9 & 1925,6 & 2324,7 & 3223,5 & 3431,1 & 4934,9 \\
\hline Other Exports & 708,8 & 920,7 & 1180,5 & 1359,3 & 1531,2 & 1689,4 & 3313,5 \\
\hline \multicolumn{8}{|l|}{$\begin{array}{l}\text { Travel \& } \\
\text { Tourism } \\
\text { Direct } \\
\text { Industry }\end{array}$} \\
\hline $\begin{array}{l}\text { Employment } \\
\text { ('000) }\end{array}$ & 371,3 & 379,8 & 372,9 & 378,4 & 383,7 & 386,2 & 477,8 \\
\hline $\begin{array}{l}\text { Gross } \\
\text { Domestic } \\
\text { Product } \\
\text { (US\$ mn) }\end{array}$ & 1730 & 2114,6 & 2480,8 & 2805,7 & 3452,3 & 3523,9 & 4801,6 \\
\hline \multicolumn{8}{|l|}{$\begin{array}{ll}\text { Travel } & \& \\
\text { Tourism } & \\
\text { Economy } & \\
\end{array}$} \\
\hline $\begin{array}{l}\text { Employment } \\
\text { ('000) }\end{array}$ & 1034,8 & 1053,6 & 1041 & 1066,3 & 1100,2 & 1121,3 & 1451,5 \\
\hline $\begin{array}{l}\text { Gross } \\
\text { Domestic } \\
\text { Product } \\
\text { (US\$ mn) }\end{array}$ & 5051,5 & 6144,9 & 7256,9 & 8290,6 & 10394,7 & 10753,3 & 15383,1 \\
\hline
\end{tabular}

E: Estimate, F: Forecast

Source: World Travel and Tourism Council 
Based on the data depicted in table one, the following patterns have been identified:

The personal travel and tourism category, defined by the WTTC as "all personal spending by an economy's residents on Travel \& Tourism services [...] and goods (durable and nondurable) used for Travel \& Tourism activities" (WTTC, 2008a, p. 8), covering all outbound and domestic travel and tourism has experienced very positive rates of growth during the last five years $(17,18,11,20$ and $8 \%)$. The same trend can be identified for the business travel and tourism category, which refers to "expenditures by government and industry including spending on goods and services for employee business travel purposes" (WTTC, 2008a, p. 8).

Concerning the latter aspect, it should be stated that unquestionably the improved security conditions in the country represent a very important determinant for the increase in both domestic and outbound tourism. The recent initiatives undertaken by the institutional setting related to the tourism sector in Colombia, dealing with a wide array of issues such as an aggressive country marketing campaign, the organization of the general assembly of the World Tourism Organization in 2008, the elimination of visas and certain procedures for a group of nations and the reduction in taxes to promote investments in the hotel sector, have proved to be fruitful. Besides this, the government has been actively involved in promoting the so-called "business tourism" through the organization of different international congresses, seminars and business events in the country.

Visitor exports, defined as "the expenditures by international visitors on goods and services within the resident economy" (WTTC, 2008a, p. 8) have also presented a very positive behavior of constant growth rates: increases of $15 \%, 15 \%, 28 \%, 9 \%$ and $3 \%$ respectively during the last five years. This appears to be a good indicator of a possible linkage effect of the Colombian tourism industry to other sectors of the national economy and would be a positive effect, namely, for Colombia to supply a relevant proportion of the goods and services consumed by tourists. Taking into account the diversified structure of the Colombian economy, this could be a good sign of the way that tourism could play a role as a driver of economic growth for the whole economy. The travel and tourism consumption, defined as "the total travel and tourism expenditures made by and on behalf of visitors (goods and services) in the resident economy" (WTTC, 2008a, p. 8) is expected to increase by an impressive $94 \%$ in 2008, compared to the value registered in 2003. The government expenditures associated to services related to tourism such as tourism promotion and administration increased by 95\%, comparing the value of 2003 to the one registered for 2007 .

The capital investment in the tourism sector, which refers to capital expenditures by direct travel and tourism industry service providers and government agencies to provide facilities, equipment and infrastructure to visitors (WTTC, 2008a, p. 8) shows a very important increase, especially for the year 2006 (21\%) and 2007 (39\%). This can be explained, to a large extent, by the tax incentives on investments in the hotel sector that have been granted for the construction of new hotels and the refurbishment or the expansion of existing ones, in force since 2003. Likewise, the government has actively been involved in promoting the construction of a wide array of new business and convention centers all around the country, expecting to specifically support the business tourism sector.

Another criterion for establishing the width and depth of tourism within the Colombian economy is related to its impact in terms of GDP contribution and employment generation. For that purpose, it is appropriate to take a first glance at the figures for the travel and tourism industry: as the WTTC states, this captures the explicitly defined production-side 'industry' 
contribution (i.e. direct impact only), for comparison with all other industries (WTTC, 2008a).

By the middle of the 1990s, as depicted below, $1.76 \%$ of employment in Colombia originated directly through the travel and tourism industry. This value peaked in 2001, reaching a level of $2.05 \%$. After experiencing a decline in 2002, the share has oscillated at levels near to $2 \%$. For 2008, the WTTC expects this participation to reach a level of $1.81 \%$. It is forecasted that for 2018 , this value will register the same participation of $1.8 \%$ (WTTC, 2008a, p. 16).

Figure 8: Travel and Tourism Industry Aggregates in Colombia (Direct Impact Only), 1996-2008

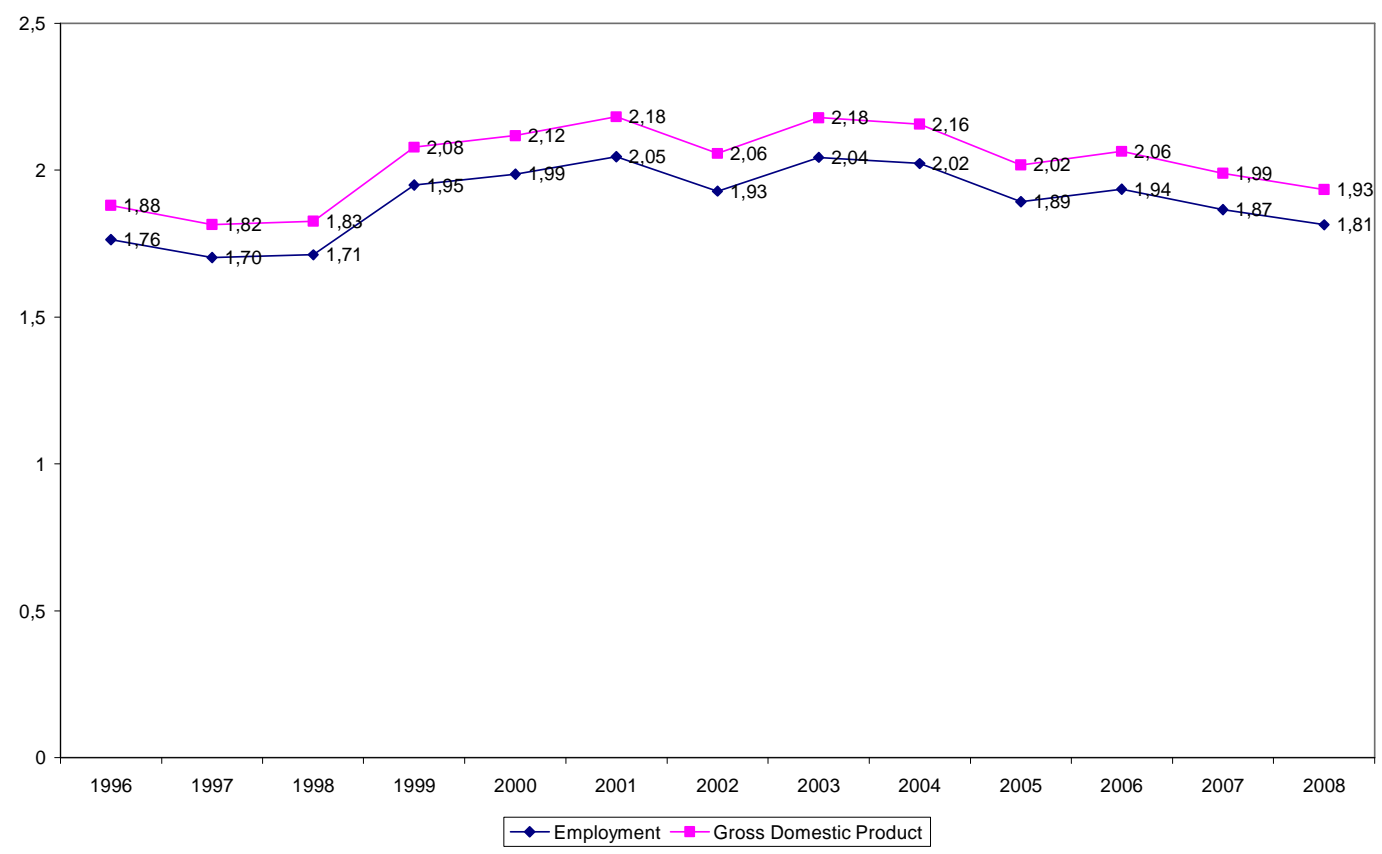

Source: World Travel and Tourism Council

GDP directly originated in the travel and tourism industry, also by the middle of the 1990s, registered a level of $1.88 \%$. As well as in the case of employment, this figure peaked in the year 2001, reaching a share of $2.18 \%$. In 2008, it is expected to reach a level of $1.93 \%$ and it is forecast to be of the order of $1.93 \%$ by 2018 .

Initially, these figures could lead to some previous reflections underestimating the economic importance of tourism in Colombia. Taking that into account, the TSA methodology incorporates the so-called "travel and tourism economy" concept, intended to reflect the broader 'economy-wide' impact, direct and indirect, of travel and tourism in a country (WTTC, 2008a). 
Figure 9: Travel and Tourism Economy Aggregates in Colombia (Direct and Indirect Impact), 1996-2008

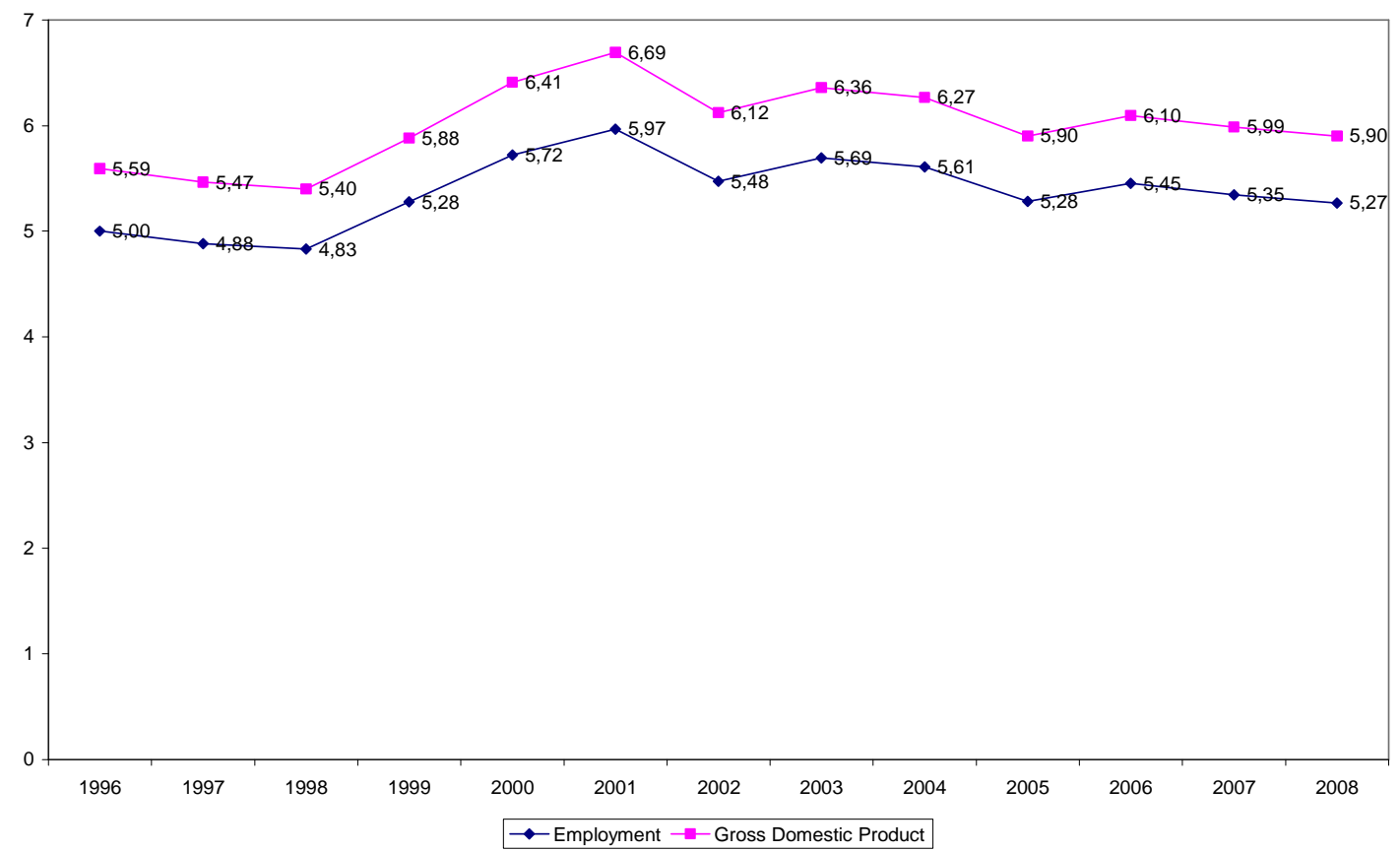

Source: World Travel and Tourism Council

The above depicted data in figure 9 allow to get a much broader perspective of tourism's importance for the Colombian economy. When summing up the direct and indirect impact of travel and tourism by the middle of the 1990s, it is possible to observe that $5.59 \%$ of the Colombian GDP was associated with tourism. This figure surged in 2001 (6.69\%), and is expected to represent a share of $5.90 \%$ for the current year. WTTC's forecasts predict that for the year 2018, it will register a value of $6.2 \%$.

As far as employment levels are concerned, the picture looks also impressively different compared to the previous graphic: $5 \%$ of national employment was associated with the tourism economy in 1996, surging in 2001 (almost 6\%) and showing a forecast of $5.27 \%$ in 2008. For the year 2018, it is expected to increase to $5.5 \%$.

While it is true that tourism plays an important role in terms of employment generation and GDP contribution, especially when the whole economic impact is considered, in contrast, its contribution in one of the lowest when compared to other Latin American countries. Concerning travel and tourism economy employment, Colombia is after Chile the second country in the region showing the smallest share of employment associated with tourism. Different to Mexico, Costa Rica or Argentina, where this share reaches a proportion of $14.3 \%$, $13.1 \%$ and $10.5 \%$ respectively, the contribution in Colombia looks rather small. This comparison is far away more striking when comparing Colombia to some small Caribbean islands whose economies are very dependent on the tourism sector (e.g Antigua \& Barbuda, Aruba or Anguilla where $87.1 \%, 81.4 \%$ and $73.7 \%$ of employment is generated by the travel and tourism economy) (WTTC, 2008b, p. 3). In that sense, it is positive to mention that while tourism is increasing its relative weight and significance in Colombia, the diversified economic structure of the country is reflected in the fact that employment generation relies strongly on other services, as well as the industry and the agricultural sector. Based on the 
latter, it could be stated that a risk of overdependence on the Colombian economy towards tourism is so far, not apparent.

Equally important is to compare Colombia with other Latin American countries, concerning the "travel and tourism economy GDP" as a percentage of the total one. While in countries such as Mexico, Costa Rica, Argentina or Ecuador this share is much more significant $(14 \%$, $13.5 \%, 8.8 \%$ and $8.1 \%$ respectively), Colombia registers with Chile the lowest levels in the region, with shares of $5.9 \%$ and $4.5 \%$ (WTTC, 2008a, p. 12).

The possible contribution of tourism in terms of FDI has also been addressed in the first sections of this paper. Therefore, it is now important to analyze how the entrance of foreign capital, especially for tourism-related projects, is contributing to Colombian economic growth.

In 1996, the Colombian Balance of Payments registered a value of FDI amounting to US \$ 3112 million. By 1999, due to the complicated internal situation and the already mentioned security conditions at the domestic level, FDI dramatically dropped to US\$ 1.508 , its lowest level within the period of time comprised between 1996-2007 (a fall of 46.7\%). Despite the recovery in 2000 and 2001, the years 2002 and 2003 showed decays of $16.1 \%$ and $19.4 \%$ with respect to the previous year. In contrast, since 2003 a positive trend of steady growth can be observed. The unexpected increase in 2005 (with a positive variation of $240 \%$ with respect to 2004) can be explained by the sale of the biggest Colombian brewery to foreign investors. Very important levels of FDI in the country have been arriving in the country since 2004.

Figure 10: Foreign Direct Investment in Colombia, US \$ Million, 1996-2007

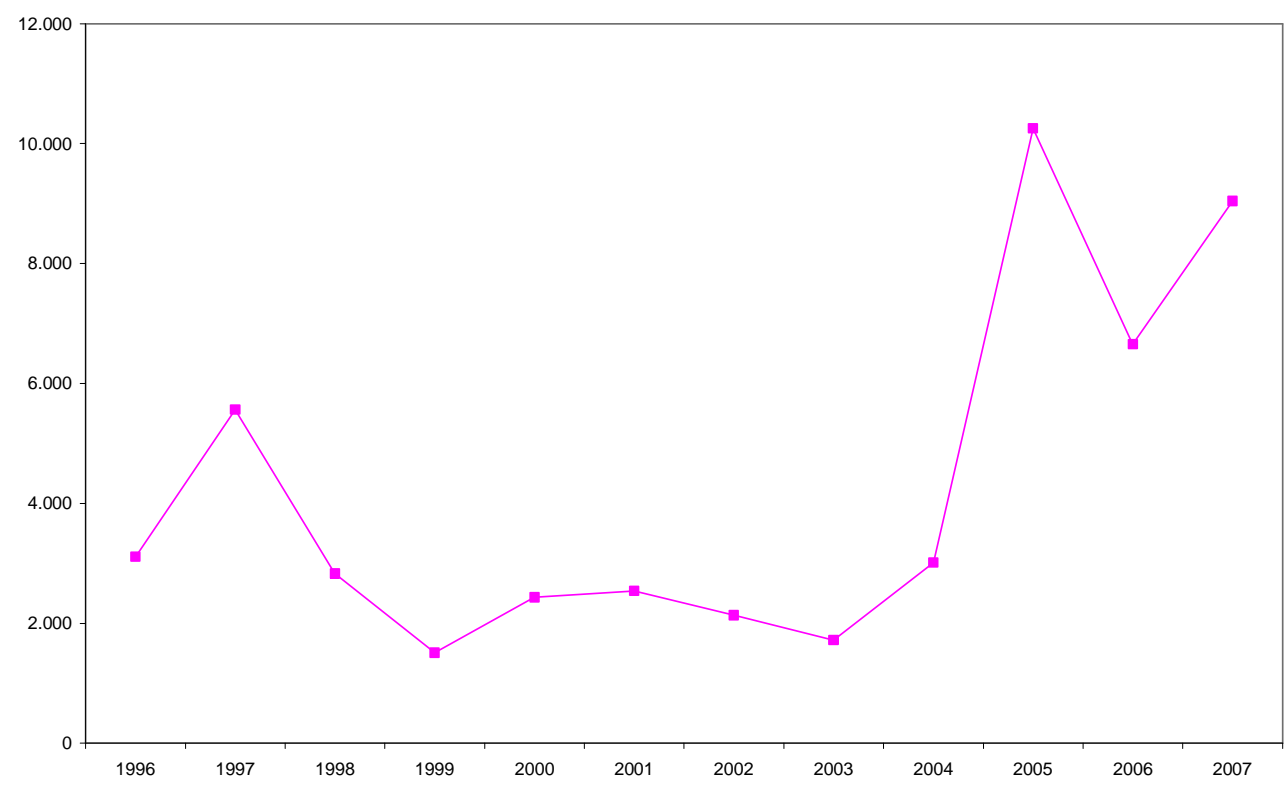

Source: Colombian National Central Bank

If the total amount of the foreign capital invested in Colombia between the years 1996-2007 is aggregated by sector, one visible trend is that the bulk of these investments has been concentrated in the manufacturing sector $(24.2 \%)$, mines and quarries $(18.1 \%)$, oil $(16.8 \%)$, financial services $(14.4 \%)$, transport, storage and communications (10.2\%), electricity, gas and water $(7.1 \%)$. Out of 10 sectors, retail, restaurants and hotels have occupied the seventh position, attracting $6.1 \%$ of the foreign capital, just surpassing construction (1.4\%), community services $(1.2 \%)$ and agriculture, hunting and forestry $(0.3 \%)$. 
In essence, it can be stated that the tourism sector in Colombia has not been one of the principal recipients of FDI in the country, a fact that can be explained taking into account different considerations such as the small priority accorded to this economic activity until 2002, the low profile of tourism within the social and economic policies formulated and again, the national security conditions which where a very hard obstacle to be overcome. It is relevant to add, as well, that traditionally tourism has been mostly of domestic character in the country. Nevertheless, since 2005 the foreign investments arriving in the retail, restaurants and hotels sectors have been steadily growing: during the last three years, increases of $50.9 \%$, $71.6 \%$ and $53.5 \%$ have taken place. This positive trend is depicted in the graphic below.

Figure 11: FDI Tourism Sector, US \$ Million, 1996-2007

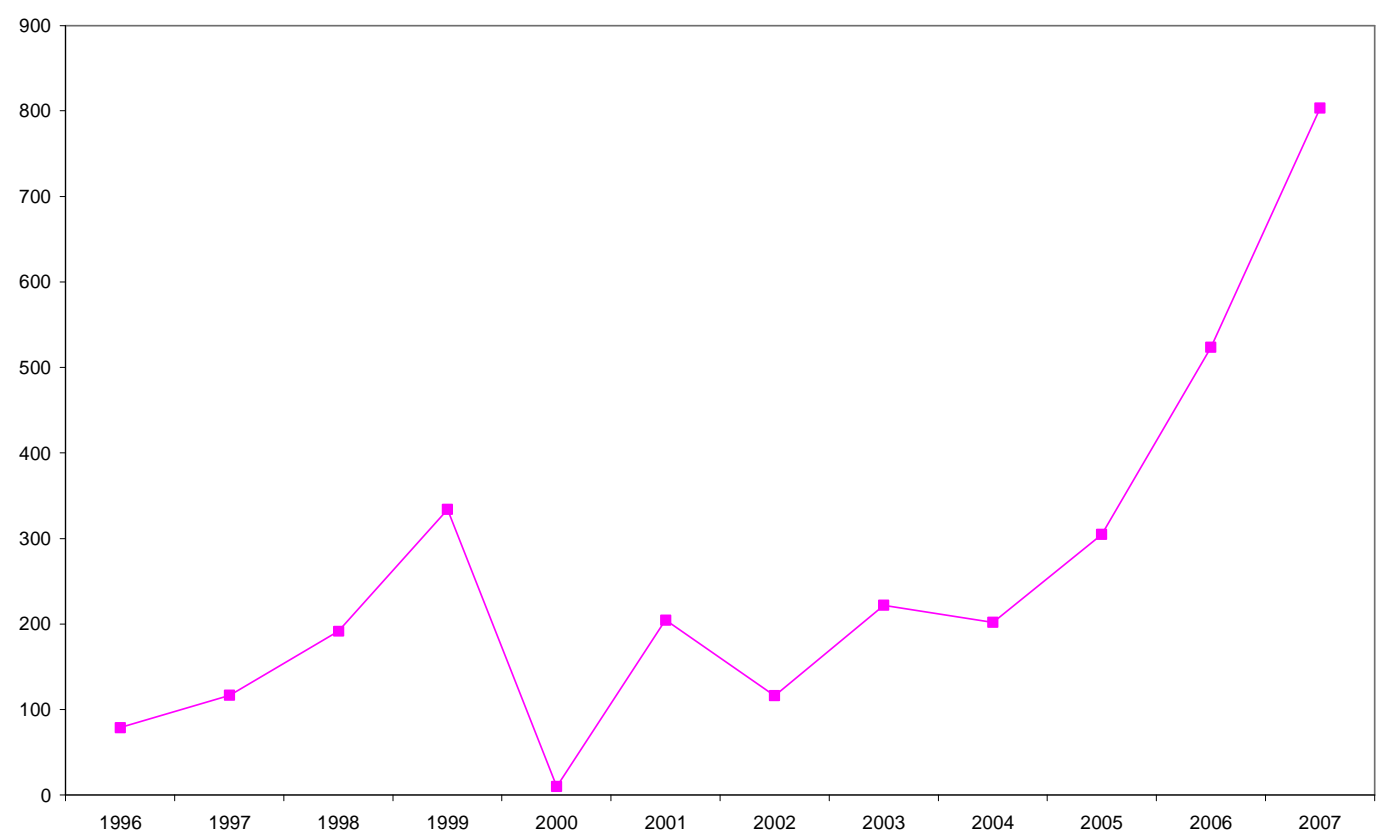

Source: Colombian National Central Bank

Colombian policy makers have defined the goal of attracting more foreign capital to the tourism sector, an objective that has been included within the "Tourism Sectoral Plan 20072010". Tax incentives on investments in the hotel sector have been introduced by law 788 from 2002, offering exemptions on earnings for 30 years for new hotels and ecotourism projects, and for 20 years for remodeling and expansion. As stated by COTELCO, the principal private association that represents the Colombian hotel sector, investments in infrastructure is increasing rapidly: hotel infrastructure is to be expanded by 20,000 new rooms (UNWTO, 2007, p. 32). New convention centers have also been constructed not just in the principal, but also in some medium-size cities such as Cali, Barranquilla, Armenia, Popayán, Villa de Leyva, Santa Marta, and San Andrés.

Hitherto, the data and statistics analyzed offer a clear perspective of the positive impact and potentiality that tourism is having within the Colombian economy, in terms of foreign currency generation, employment, GDP participation, its broader linkage to other economic sectors and finally, concerning the increase in the capital investments. The TSA-derived statistics show that the sector has a lot of forward and backward linkages in Colombia, with potential for multiplier and spill-over effects on the rest of the economy. Linking this with some previous arguments introduced in former sections of our paper where it was stated how 
international tourism has become an appealing option for economic development, it seems to be that tourism could play that role in Colombia. Moreover, it is positive to identify how tourism is being targeted as a "driver" of economic growth but in no way as a single and unique source of economic development. The industrial sector, non-tourism services and to a lesser extent even agriculture, are important supporters of Colombian economic growth. Approaching international tourism, rather than the domestic one, is a fairly recent development in Colombia.

Now it is time to analyze how Colombia is performing, with regard to the so-called "social capabilities" (human capital and institutional arrangements) and the innovation potentials in tourism services. The argument that these could be observed as supply factors of tourism has already been put forward.

The quality of human capital should be of paramount importance for the Colombian tourism industry, both in terms of skilled and semi-skilled workers. For evaluating this factor, one important source could be the so-called Travel and Tourism Competitiveness Index (TTCI) which has recently been introduced by The World Economic Forum to measure the level of competitiveness in tourism worldwide. For that purpose, 14 "pillars" have been evaluated in 130 nations, being grouped into three sub-indexes: regulatory framework (five pillars), business environment and infrastructure (five pillars), as well as human, cultural, and natural resources (four pillars) (WEF, 2008). Despite the very recent introduction of this indicator (launched in 2007), the results of this evaluation for Colombia allow to get a "snapshot" of the aspects where it needs to improve and carefully review its policies concerning the tourism sector.

At an aggregate level, Colombia's scores are not the best: it ranks number 71 in the world, number 13 in Latin America and the Caribbean (WEF, 2008, p.154). While the average grade for the same region was 3.92, Colombia's was 3.86. A reason for that occurring is that the scores obtained in the sub-indexes "regulatory framework" and "business environment and infrastructure" are not good. Something striking, yet promising, about the report is the good grades that the country gets in practically all the pillars within the sub-index "human, cultural, and natural resources".

Before addressing the topic of education and human capital, it should be mentioned that according to the same study, the principal factors where Colombia must strongly work to increase its competitiveness in the tourism sector have to do with the time and cost required to start a business, the environmental sustainability (especially the criteria "threatened species" and "environmental treaty ratification") and safety and security (business costs of terrorism, and of crime and violence, road traffic accidents). Colombia, for instance, occupies the very concerning position of 128th out of 130 countries when it comes to business costs of terrorism (WEF, 2008, p. 390). While business costs of crime and violence are also a matter of concern, it is interesting to notice how the country gets a better score compared to other most recognized Latin American and Caribbean destinations, such as Jamaica, Brazil, Mexico or Peru.

Furthermore, The National Council of Economic and Social Policy (Consejo Nacional de Política Económica y Social, CONPES) elaborated in 2005 the so-called "Sectoral Tourism Policy", which includes the general guidelines for the development of an integral tourism policy in Colombia. Within this document, the government recognizes that despite the natural and cultural wealth of the country, an ample variety of factors place obstacles against the 
competitiveness of the sector, these limitations are also mentioned within the World Economic Forum's report. Some of these aspects have to do with infrastructure and transport, the scarcity of the installed tourism capacity in some regions, the access to financing, safety and security or the deficiency in the formulation and application of tourism policies.

Another important factor where Colombia shows a poor record is the one related to ground transport infrastructure: this has to do with the quality of the roads, as well as with the quality of the railroad and port infrastructure. Most concerning is the fact that Colombia is one of the countries in Latin America with the poorest record, when it comes to road density. This is, of course, a factor that directly undermines Colombian competitiveness not just in the tourism sector, but in the whole economy.

As to education, according to UNESCO Colombia has a net enrolment rate of $87 \%$ at the primary level, $67 \%$ at the secondary level (the latter has increased positively during recent years, being $55 \%$ in 2004, but still below the regional average of $70 \%$ ) and a remarkably low gross enrolment rate of $32 \%$ at the tertiary level (which has also been dramatically improved, from levels of $24 \%$ in 2002, being near to the regional average of $34 \%$ ). Despite these enrolment rates having impressively improved during recent years, Colombian indicators reflect how a broader coverage at all levels of education is badly needed: especially when it comes to secondary and tertiary levels, the country does not occupy a good position in Latin America, lagging behind other countries such as Mexico, Cuba, Peru, Bolivia and Venezuela.

However, it is positive to find out that improvements have been accomplished recently: one promising aspect is that the Colombian government has augmented its public expenditure on education as a percentage of the GDP: from $4.2 \%$ in the year 2000, it went to $4.7 \%$ in 2006, being now on the same level as Costa Rica. Literacy rates in Colombia are above the region's average, at 92.3\% . (http://stats.uis.unesco.org/unesco/TableViewer/document.aspx?ReportId= $121 \& I F \_L a n g u a g e=e n g \& B R \_C o u n t r y=1700 \& B R \_$Region $\left.=40520,2006\right)$.

Additionally, one of the highest scores given to Colombia by the World Economic Forum within the TTCI is the one related to the quality of the educational system, where the country is recognized ,after Costa Rica, as the second best positioned in the whole Latin American and Caribbean region. Other indicators where Colombia shows good results are the ones concerning the easiness of the labor regulation for hiring foreign labor.

As far as the tertiary education in the tourism field is concerned, it is satisfactory to identify how the country counts on a wide offer of programs at the technical, bachelor and master levels. According to the Colombian Ministry of Education, there are 37 programs in the country at the technical-technological level, 20 bachelor programs and 12 postgraduate programs. Nevertheless, it is important to notice that these programs are highly concentrated in some main urban centers and are not easily accessible to many provincial regions.

Colombian policy-makers are aware of the importance of human capital within the tourism sector, which can be easily proved when taking a look at the previously mentioned "Tourism Sectoral Policy 2008-2010". The objective of including a subject related to tourism both at the secondary and tertiary level is explicitly mentioned. One of the most important strategies expressed in the same document is the one regarding the promotion of a "culture of tourism" at the national level, through education. This makes reference to the necessity of raising awareness of the importance of tourism for economic growth, among the actors involved. Reference is also made to the necessity of applying the so-called "Plan for Education in the 
Colombian Tourism Sector", elaborated by the Ministry of Commerce, Industry and Tourism, launched in the year 2005, which contains guidelines for the enhancement of human capital in the tourism sector.

The Colombian government, through its "Sectoral Tourism Policy" of 2005, expresses its commitment towards the improvement of education and training of the human capital involved with this sector. Taking into account that the big majority of tourism providers are comprised of micro and small enterprises, the underlying purpose is to support them to attain better levels of quality with the services they offer. Consequently, the formation of these entrepreneurs, both in managerial and tourism-related skills, is foreseen. Also, to improve the quality of education based on actions such as the incorporation of elective courses in tourism at school level and to strengthen programs related to work competences, are important objectives.

Another initiative being currently undertaken in Colombia is the one concerned with different training programs that are being offered to different actors within the tourism sector. The underlying idea of the program is to support a competitive offer and to improve the quality of the service provided to international tourists, objective to be accomplished through workshops and conferences all around the country, contributing to the generation of a "tourism culture". These training sessions are offered to a variety of audiences, ranging from hoteliers to restaurant owners and employees, travel agencies and tourism guides (http://www.proexport.com.co/vbecontent/newsdetail.asp?id=9334\&idcompany=20\&ItemMe $\left.\mathrm{nu}=2 \_250,2008\right)$.

Equally important, the results of the evaluations made by the World Economic Forum associated to the ninth pillar (ICT infrastructure) should also be a matter of reflection to policy-makers in Colombia. Beginning with the extent of business internet use in the tourism sector, the country's position is not outstanding: it gets a score of 3.7 out of 7, lagging behind many countries in Latin America and the Caribbean, showing how the extent of business internet use within tourism-related companies is still limited (WEF, 2008, p. 426).

This is also mentioned in the study "Occupational Characterization of the Tourism Sector", elaborated by the National Apprenticeship System (SENA) as an institution attached to the Colombian government, pointing out that there are some provincial regions in Colombia where still the use of internet within companies associated to the tourism sector is very limited. A general characteristic of the tourism service providers is the small amount of investment in technologies. This is due to the fact that the big majority of economic unities within the tourism sector are small and medium companies, which frequently do not count on sufficient economic resources for undertaking these investments.

The same study includes a survey conducted within the hotel and lodging sector in Colombia showing that $49 \%$ of the companies registered in the so-called "National Tourism Register" are scarcely using ICTs. $56 \%$ of these companies stated that they did not use computers within their daily operations and $64 \%$ do not have access to the Internet. Travel agencies and tour operators show a much more relevant incorporation of ICTs: $92 \%$ of them expressed that they effectively use them. $87 \%$ of travel agencies do have access to the Internet (SENA, 2006, pp. 50-51).

Colombian policy-makers are aware that the country is lagging behind in technologies in general, not just the ones concerning the tourism sector. The latest World Economic Forum's 
Global Competitiveness Index poorly grades Colombia, when it comes to the criteria "technological readiness"": the country gets 3.1 out of 7.0 possible points. Availability of latest technologies gets 3.7, firm-level technology absorption obtains 4.2, FDI and technology transfer 4.6. Regarding innovation, the country obtains a score of 3.2 (WEF, 2008, p. 463). As stated by the SENA, in Colombia the current ICT status does not reflect the advances of the economy: it is one of the most backward nations as far as the incorporation of ICTs is concerned.

Taking this technological gap into account, the so-called "Connectivity Agenda" (Agenda de Conectividad) has been launched since the year 2000, being defined as a group of actions oriented towards encouraging the social and economic development of Colombia, through the massification of information and communication technologies. It remains to be seen how long it will take for these national policies to be actively implemented, not just within the tourism sector but through the economy as a whole.

Despite the categorization of tourism as a personal service, it is unquestionable that there is a great potentiality to increase its productivity and efficiency through incorporating ICTs. Nowadays, information technologies are having a great impact over the entire value chain of tourism and its related sectors. They allow to offer new services, much more competitive in terms of costs, such as specialized websites for making reservations, selecting tourism destinations, etc. In addition, they increase the efficiency of units such as hotels, lodgings and restaurants. Many different information technologies may be associated with tourism, e.g. booking systems, teleconferences, systems of management information, digital networks, mobile communications, e-business and many others (SENA, 2006, p.44).

With respect to the applied research generated in Colombia within the tourism field, the SENA's study underscores the great lack of investigation within this sector, at the national level. Some universities have, separately from each other, established lines of research in tourism, but a network does not exist. Another limitation is that these investigations are basically undertaken without considering the necessities of the other sectors and actors involved in the tourism sector (SENA, 2006, p. 58),

The institutional setting plays also a very important role within the so-called "social capabilities". For the particular case of Colombia, the newest institutional tourism setting was introduced by the "Sectoral Tourism Policy" of 2005, approved by the National Economic and Social Council. In first place, it bestows the Ministry of Commerce, Industry and Tourism with the responsibilities of formulating the tourism policies, coordinating the actions of the different tourism-related institutions, offering technical assistance to the different regions, and promoting the improvement of the sector's quality standards, among others.

Under its coordination, all the national and regional entities are supposed to get involved within the sector's development strategy, such as the Education Ministry, Ministry of Environmental Affairs, Ministry of Transport, Ministry of Culture, among many others, taking into account the guidelines provided by the National Development Plan.

\footnotetext{
${ }^{9}$ According to the WEF "this pillar measures the agility with which an economy adopts existing technologies to enhance the productivity of its industries. ICT access (including the presence of an ICT-friendly regulatory framework) and usage are included in the pillar as essential components of economies' overall level of technological readiness" (WEF, 2008, p. 5).
} 
With regard to financing of projects dealing with the promotion of the country (image building) and the betterment of tourism sector competitiveness, the Tourism Promotion Fund (Fondo de Promoción Turística) will be in charge. Its resources proceed from different taxes and contributions and are basically intended to support the training and education programs, and promotion strategies.

Proexport is called to undertake the promotion of Colombian tourism at international level (image building, country brand, assistance to international tourism fairs), as well as the conduction of market studies leading to the identification of business opportunities for the tourism sector at international level.

\section{Conclusions and some policy recommendations along the "social capabilities"}

This paper represents some theoretical insights into the structural change theory, whereby supply-side explanations have to be extended by demand-side elements, a categorization of services, ICT use, human capital and institutional factors of structural change. These explanations are used to describe the main characteristics of the tourism sector with special emphasis on consumer taste changes and innovation potentials. In general, the importance of innovation for the service sectors is under-researched and underestimated in literature although the contributions especially of the OECD made this topic aware in recent years. ${ }^{10}$ To study the potential of these determinants for the tourism sector, we have to divide the tourism supply into homogenous (based on price competitiveness) and individualistic components which promote the quality and uniqueness of tourism offer. No other sector is much more affected by globalisation pressures than this sector offering ambiguous contributions to the economic development of a country. Thus, in particular, diversification is the most important market strategy of destinations in the future. As a mainly labour-intensive sector, institutional set-up, human capital as well as the role of SMEs versus MNCs for a "sustainable development" were examined.

First and foremost, it should be stated that tourism has unquestionably brought some positive effects for Colombia. The analysis of the secondary data gathered show how the impact of the so-called "tourism economy" can not be overlooked: its impact on the whole economy is relevant, in terms of GDP, employment, personal spending by residents on travel and tourism services, expenditure by government, as well as industry and visitor exports, that have also been steadily growing. The latter could be considered as a good indicator of a possible linkage effect of the Colombian tourism industry to other sectors of the national economy. The increase of FDI being attracted to the Colombian tourism sector, as well as the augmentation of the capital investment levels, should also be recognized as positive effects.

Another positive aspect to be mentioned is related to the fact that Colombia is not - and is not planning to become - a "tourism-dependent" country. International comparisons demonstrate that the Colombian economy is one of the least dependent in Latin America from the tourism sector, in terms of employment and GDP shares alike. Sinclair's (1998) important observation that tourism could eventually become a risky option for developing countries strongly dependent on this economic activity, considering the unstable character of the earnings

\footnotetext{
${ }^{10}$ See for example the OECD reports "Innovation and Productivity in Services" in 2001 or "Enhancing the Performance in the Service sectors" in 2005.
} 
associated to it, is not applicable to the Colombian case. The most important earnings in the country have proceeded both from traditional and non-traditional exports different to services. Traditionally, the so-called Colombian "traditional" and "non-traditional" exports have had the most important share of exports registered in the balance of payments: for accounting purposes, the Colombian National Central Bank groups coffee, oil and its derivatives, coal and nickel within the traditional exports. Non-traditional exports are comprised of flowers, emeralds, minerals such as gold, and a big variety of agro-industrial and industrial products. Services have traditionally occupied the third position among the most important Colombian exports and even though tourism's participation has importantly increased since 2003, its contribution amounts to $8 \%$ of the Colombian total exports.

Through this paper, a somehow paradoxical trend has been shown to be unfolding: while the importance of tourism for the foreign currency generation has become more significant, in contrast, its relative weight within the total amount of foreign currency registered in the balance of payments has actually decreased. Traditional and non-traditional exports, as well as services different to tourism, represent a crucial source of income. The principal recipients of FDI in Colombia are non-tourism sectors, as has been already mentioned. The strategy of diversifying the Colombian exports seems to be successful, so far. And up to now, the country is not facing the challenge of getting involved in the "risky option" that Sinclair mentions.

Colombian policy-makers should be aware of some "strings attached", when considering tourism for encouraging sustained and stable economic growth, as well as for contributing to alleviate poverty in the country. First of all, the structurally "seasonal" character of this economic activity makes it also a "risky option", as defined by Sinclair. In that sense of the word, the current strategies formulated to develop different types of tourism (eco-, business, cultural, health, as well as sun and sea tourism) are adequate. Moreover, it should be noted that tourism is sensitive, to a great extent, to safety and security considerations. The unquestionably positive results in that field since 2003 are visible, so is the effect that they have had on tourism as well. A daunting task, nevertheless, is related to guaranteeing that these security conditions will be improved: they are still insufficient, when international standards are considered and should have a more widespread impact over the whole territory. This continues to be a factor that negatively limits the competitiveness of the Colombian tourism industry, as shown by studies such as the one conducted by the World Economic Forum through its Travel and Tourism Competitiveness Index.

One important objective pursued with this paper has been to analyze how a "follower" country like Colombia shows potentialities for increasing the positive economic contribution of tourism, which according to Abramovitz, could be accomplished by renewing the capital stock, adopting best-practice technologies, backing up innovations through R\&D efforts and very importantly, guaranteeing that the appropriate "absorptive capability" is available.

The results obtained by the study conducted allowed to demonstrate that Colombia is a country that is lagging behind in technology at all levels of the economy. As far as ICT incorporation in the tourism sector is concerned, a striking finding is related to the fact that the country has a very scarce degree of access not just to the latest, but even the most basic technologies needed. Within the framework of the "Connectivity Agenda", concrete strategies should be formulated for tackling this grave constraint that limits the productivity and efficiency and undermines the competitiveness of the Colombian tourism sector. Initiatives for supporting SMEs, which are the big majority of economic units in the sector, should be 
urgently formulated: especially concerning the financing of these investments, which is one of the most important reasons why many entrepreneurs do not invest in technologies.

The increase of FDI in the Colombian tourism sector should be viewed as a positive development since 2005. Nevertheless, it should be noted that Colombian SMEs play the most important role in the tourism offer. Taking that into account, besides promoting the entrance of foreign competitors into the market, one crucial aspect to be addressed is how to ensure that an effective technology transfer takes place. Besides the government's support of the national entrepreneurs when upgrading its stock of capital and incorporating technologies, international franchises could be evaluated as another viable way for many of these companies to stay in the market and become competitive.

Ecotourism, as one of the sectors being considered in Colombia within its tourism plans, depicts great possibilities for small and medium companies to offer, in a competitive way, environmentally-friendly opportunities of leisure. The Costa Rican case, for instance, has shown positive results for many SMEs in that country. Taking into account that Colombian policy-makers have expressed their intention of directing their efforts mainly to establish a differentiated, sophisticated and unique type of tourism (a strategy that would allow attracting high-income tourists), a wide array of actions should be undertaken to promote this sector. While it is true that the country shows important potentialities in this sector, it is of pivotal importance to take into account the very serious limitations concerning the education and skills of the actors involved: many of the natural parks and protected areas in the country are precisely located in very poor, distant regions of the territory, where access to education is insufficient and very poor communities live.

Within the ecotourism sector, previous cases have demonstrated that it is of pivotal importance to integrate the communities, to raise the awareness of the wealth that the environment represents, to train the people with special skills and knowledge and to generate positive visible impacts for the inhabitants of these regions in economic terms. Ecotourism has very recently been considered in Colombia as a possible source of income and employment. It is important to clarify that the country already counts on a national ecotourism policy that was elaborated by the current administration. It remains to be seen whether the ambitious strategies related not just to improving education, but also to issues such as the definition of responsibilities of the different actors involved, the surveillance of the possible impacts or the development of quality standards, are effectively implemented.

Despite the visible accomplishments in Colombia in the field of education, especially dealing with its quality, a factor that is internationally recognized in many reports and studies, increasing the coverage of education in the country is urgently needed, especially at secondary and tertiary levels. When specifically analyzing the tourism-related education offer, some limitations reach the surface: efforts should be undertaken to promote a wider offer of tourism-related studies at the public level. Most of the programs at the technical, technological and university levels are provided by private universities. Many of these programs are concentrated in the big urban centers, while the offer at the provincial level is rather scarce. It is of great importance that public universities and institutions, as well as the SENA, introduce a wider array of possibilities for people that are not able to afford private education.

Colombian policy makers have proved to significantly boost the capital investments in the tourism sector, based on the tax incentives offered in the hotel sector to the exemptions on 
earnings for 30 years for new hotels and ecotourism projects, and for 20 years for remodeling and expansion. But as expressed by Copeland (1991), revenues generated for the governments by the way of taxes to tourism are also relevant arguments. Considering that, as well as the problem of the so-called "unpriced natural amenities", the recently introduced "tourism tax", which since the year 2007 is applied to all foreign tourists entering the national territory by plane, is appropriate. However, the destination of these incomes does not seem to fully tackle the problem of preserving and sustaining the Colombian natural resources and biodiversity: it is foreseen that the earnings should be directed mainly towards the country's international promotion and "image building" activities.

One urgent priority is to invest and to economically support the conservation of this natural wealth, as well as to ensure some economic profits to the communities and actors involved within the ecotourism sector.

Finally, the Colombian case depicts the combination of a "technological gap" and "social capabilities" available that, in Abramovitz's words, "could lead to a productivity advance" in the tourism sector. The issue of technological backwardness and the good, but poorly disseminated, education has already been addressed. It should be added that the institutional setting in Colombia dealing with the tourism sector has been effectively upgraded and supported since 2002. National tourism policies do exist, objectives and strategies are clear, the responsibilities of the different institutions have been defined. These are optimistic signs that unveil potentialities for a developing country like Colombia to obtain profit, in a much wider and profound manner, from the opportunities that tourism offers. 


\section{References}

Abramovitz, M., (1986), Catching up, Forging Ahead, and Falling Behind, in: Journal of Economic History, Vol. 46, no. 2, 385-406, here in: Abramovitz, M. (1989), Thinking about Growth, Cambridge, 220-242.

Algieri, B., (2006), International Tourism Specialisation of Small Countries, International Journal of Tourism Research, Vol. 8, 1-12.

Arrow, K. J., (1962), The Economic Implications of Learning by Doing, Review of Economic Studies, Vol. 29, No.3, 155-173.

Baumol, W. J., (1967), Macroeconomics of Unbalanced Growth: the Anatomy of Urban Crises, American Economic Review, Vol. 58, no. 4, 415 - 426.

Baumol, W. J., Batey Blackman, S. A., Wolff, E. N., (1985), Unbalanced Growth Revisited: Asymptotic Stagnancy and New Evidence, American Economic Review, Vol. 75, no. 4, 806 - 817.

Baumol, W. J., Batey Blackman, S. A., Wolff, E. N., (1989), Productivity and American leadership: the long view, The MIT Press, Cambridge, London.

Becker, G., (1964), Human Capital - A Theoretical and Empirical Analysis with Special Reference to Education, Chicago, London.

Blake, A., (2000), The Economic Effects of Tourism in Spain, Tourism and Travel Research Institute Discussion Paper 2000/2, University of Nottingham, Nottingham.

Brida et al. (2007), The Economic Contribution of Tourism Sector, 2008 (online). Available: http://papers.ssrn.com/sol3/papers.cfm?abstract_id=1099042 (Accessed December 8, 2008)

Castells, M. Aoyama, Y., (1994), Paths toward the informational society: Employment structure in G-7 countries, 1920 - 90, International Labour Review, Vol. 133, no. 1, 5-33.

Cazes, S., Nesporova, A., (2007), Flexicurity - A relevant approach in Central and Eastern Europe, Geneva.

Clark, C., (1940), The Conditions of Economic Progress, Macmillan, London.

Copeland, B.R., (1991), Tourism, Welfare and De-industrialization in a Small Open Economy, Economica, New Series, Vol. 58, No. 232, 515-529.

Cortés-Jiménez, I., (2008), Which Type of Tourism Matters to the Regional Economic Growth? The Cases of Spain and Italy, International Journal of Tourism Research, Volume 10, Issue 2, 127-139.

Dyker, D. A., Radošević, S., (2001), Building Social Capability for Economic Catch-up: The Experience and Prospects of the Post-socialist Countries, The European Journal of Social Sciences, Vol. 14, no. 3, 219-237.

Elfring, T., (1989), 'New Evidence on the Expansion of Service Employment in Advanced Economies, Review of Income and Wealth, Vol. 35, no. 4, 409-440.

Estadísticas, el sector de servicios en el mundo (online), 2006. Available: http://www.mincomercio.gov.co/eContent/newsdetail.asp?id=5393\&idcompany=1 (Accessed December 15, 2008).

Fisher, A. G. B., (1939), Production, Primary, Secondary and Tertiary, The Economic Record, Vol. 15, 22 - 38.

Fourastié, J., (1949), Le Grand Espoir du XX Siècle : Progrès Technique - Progrès Economique - Progrès Social, Gallimard, Paris.

Gundlach, E., (1994), Demand Bias as an Explanation for Structural Change, Kyklos, Vol. 47, no. 2, 249-267. 
Javor, A., (2005), Using statistics to measure potentials for regional development of Croatia, available: http://www.ine.es/forumtur/supporting/supporting_territorial\%20approach/Using\%20tourism\%20statistics\%20to $\% 20$ measure\%20potential_PAP.pdf (Accessed December 17, 2007).

Keller, P., (2006), Innovation and tourism policy, Innovation and Growth in Tourism, OECD, Paris, S. 17 - 40.

Lucas, R.E., (1988), On the mechanics of economic development, Journal of Monetary Economics, Vol. 22, 342.

Mervar, A., Payne, J. E., (2007), An Analysis of Foreign Tourism Demand for Croatian Destinations: Long-Run Elasticity Estimates, EIZ Working Paper, EIZ-WP-0701.

Mihaljek, D., (2005), Free movement of capital, the real estate market and tourism: a blessing or a curse for Croatia on its way to the European Union?, in Ott, K., (ed.), Croatian Accession to the European Union: Facing the Challenges of Negotiations, Vol. 3., Institute of Public Finance and Friedrich Ebert Foundation, Zagreb, 181222.

Mincomercio - Ministerio de Comercio, Industria y Turismo (2008), Plan Sectorial de Turismo 2008-2010 (online), 2008. Available: http://www.mincomercio.gov.co/eContent/newsdetail.asp?id=1118\&idcompany=1. (Accessed November 30, 2008).

Mincomercio - Ministerio de Comercio, Industria y Turismo (2008),Política Nacional de Turismo 2008-2010 (online), 2008. Available:

http://www.mincomercio.gov.co/eContent/Documentos/turismo/2008/PlanSectoria2007-2010-2.pdf (Accessed December 15, 2008)

Nordhaus, W. D., (2008), Baumol's Diseases: A Macroeconomic Perspective, The B.E. Journal of Macroeconomics: Vol. 8: Iss. 1 (Contributions), Article 9., available: http://www.bepress.com/bejm/vol8/iss1/art9 (Accessed May 20, 2008)

OECD (2001), Innovation and Productivity in Services, Paris.

OECD (2005), Enhancing the Performance in the Service sectors, Paris.

Pasinetti, L. (1981), Structural Change and Economic Growth - A Theoretical Essay on the Dynamics of the Wealth of Nations, Cambridge.

Pugno, M., (2006), The service paradox and endogenous economic growth, Structural Change and Economic Dynamics, Vol. 17, 99-115.

Rogers, M., (2004), Absorptive capability and economic growth: how do countries catch-up?, Cambridge Journal of Economics, Vol. 28, no. 4, 577-596.

Schumpeter, A., (1934), The Theory of Economic Development, Cambridge, Mass..

Servicio Nacional de Aprendizaje - SENA (2006), Caracterización Ocupacional Sector Turismo (online), 2006. Available: http://www.mincomercio.gov.co/econtent/Documentos/turismo/2006/EstudioCaracterizacion.pdf (Accessed November 7, 2008).

Sequeira, T.N., Campos, C., (2005), International Tourism and Economic Growth: A Panel Data Approach, available: http://www.feem.it/NR/rdonlyres/89519C3D-0544-4E07-B34A-BDF8A810E641/1796/14105.pdf (Accessed December 29, 2007).

Sinclair, M. T., (1998), Tourism and economic development: a survey, The Journal of Development Studies, Vol. 34, no. 5, 1-51.

Temple, J., Johnson, P. A., (1998), Social Capability and Economic Growth, The Quarterly Journal of Economics, Vol. 113, no. 3, 965-990. 
TSA Definitions and Methodology (online), 2007. Available:

http://www.wttc.org/eng/Tourism_Research/Tourism_Satellite_Accounting/TSA_Definitions_and_Methodology 2007 (Accessed December 8, 2008).

Tourism Satellite Accounting (online), 2007.

Available: http://www.wttc.org/eng/Tourism_Research/Tourism_Satellite_Accounting (Accessed December 15, 2008).

Triplett, J. E., Bosworth, B. P., (2003), Productivity Measurement Issues in Services Industries: 'Baumol's Disease' has been cured, FRBNY Economic Policy Review, September 2003, 23-33.

Turismo, Noticias (online), 2008. Available:

http://www.mincomercio.gov.co/eContent/newsdetail.asp?id=5393\&idcompany=1, 2006 (Accessed December 8, 2008)

UIS Statistics in Brief (online), 2006. Available:

http://stats.uis.unesco.org/unesco/TableViewer/document.aspx?ReportId=121\&IF_Language=eng\&BR_Country $=1700 \&$ BR_Region $=40520$

UNWTO,(2008), Tourism Highlights, 2008 Edition (online), $2008 . \quad$ Available: http://www.unwto.org/facts/eng/pdf/highlights/UNWTO_Highlights08_en_HR.pdf (Accessed December 15, 2008).

UNWTO, (2007), World Tourism Barometer, Volume 5, No.3 (online), 2007. Available: http://www.unwto.org/facts/eng/pdf/barometer/UNWTO_Barom07_3_en.pdf (Accessed November 30, 2008)

Villar, L., (2000), ¿La economía colombiana se abrió o se cerró en la década de los noventa? Una nota sobre indicadores de apertura económica, Revista del Banco de la República, Vol. 73, no. 867, 1-5.

Weiermair, K., (2006), Product improvement or innovation: What is the key to success in tourism?, Innovation and Growth in Tourism, OECD, Paris, 53 - 69.

Wölfl, A., (2003), Productivity Growth in Services Industries: Is There a Role for Measurement?, International Productivity Monitor, no. 8, 6-80.

Wolfe, J.N., (1955), The Concept of Economic Sectors, The Quarterly Journal of Economics, Vol. 69, 402-420.

World Economic Forum (WEF), 2008, The Travel and Tourism Competitiveness Report 2008 (online), 2008. Available: http://www.weforum.org/ttcr08browse/index.html (Accessed November 30, 2008).

World Travel and Tourism Council (WTTC), 2008a, The 2008 Travel \& Tourism Economic Research: Colombia (online), 2008. Available: http://www.wttc.org/bin/pdf/original_pdf_file/colombia.pdf

World Travel and Tourism Council (WTTC), 2008b, Top Ten Tables (online), 2008. Available: http://www.wttc.org/bin/pdf/original_pdf_file/newleaguetablesummary.pdf 